\title{
Pingo drilling reveals sodium-chloride-dominated massive ice in Grøndalen, Spitsbergen
}

\author{
Vasiliy Demidov $^{1}$ (ㅇ | Sebastian Wetterich ${ }^{2}$ (1) | Nikita Demidov ${ }^{1}$ | \\ Lutz Schirrmeister $^{2}$ | Sergey Verkulich ${ }^{1}$ | Andrey Koshurnikov ${ }^{3}$ | \\ Vladimir Gagarin $^{3}$ | Aleksey Ekaykin ${ }^{1,4}$ | Anton Terekchov ${ }^{1}$ (ㅇ | Arina Veres ${ }^{1,4}$ | \\ Anna Kozachek ${ }^{1}$
}

${ }^{1}$ Arctic and Antarctic Research Institute,

St. Petersburg, Russia

${ }^{2}$ Department of Permafrost Research, Alfred Wegener Institute Helmholtz Center for Polar and Marine Research, Potsdam, Germany

${ }^{3}$ Faculty of Geology, GSP-1, Moscow State

University, Moscow, Russia

${ }^{4}$ St. Petersburg State University,

St. Petersburg, Russia

\section{Correspondence}

Vasiliy Demidov, Arctic and Antarctic Research Institute, Bering St. 38, 199397 St. Petersburg,

Russia.

Email: vasdemidov@mail.ru

Funding information

Deutsche Forschungsgemeinschaft, Grant/

Award Number: WE4390/7-1; Russian Science

Foundation, Grant/Award Number:

19-77-10066

\begin{abstract}
Drilling of a 21.8-m-deep borehole on top of the 10.5-m-high Nori pingo that stands at $32 \mathrm{~m}$ asl in Grøndalen Valley (Spitsbergen) revealed a 16.1-m-thick massive ice enclosed by frozen sediments. The hydrochemical compositions of both the massive ice and the sediment extract show a prevalence of $\mathrm{Na}^{+}$and $\mathrm{Cl}^{-}$ions throughout the core. The upper part of the massive ice (stage $A$ ) has low mineralization and shows an isotopically closed-system trend in $\delta^{18} \mathrm{O}$ and $\delta \mathrm{D}$ isotopes decreasing down-core. Stage B exhibits high mineralization and an isotopically semi-open system. The crystallographic structure of Nori pingo's massive ice provides evidence of several large groundwater intrusions that support the defined formation stages. Analysis of local aquifers leads to suggest that the pingo was hydraulically sourced through a local fault zone by low mineralized sodium-bicarbonate groundwater of a Paleogene strata aquifer. This groundwater was enriched by sodium and chloride ions while filtering through marine valley sediments with residual salinity. The comparison between the sodium-chloride-dominated massive ice of the Nori pingo and the sodium-bicarbonate-dominated ice of the adjacent Fili pingo that stands higher up the valley may serve as an indicator for groundwater source patterns of other Nordenskiöld Land pingos.

KEYWORDS

hydrochemistry, massive ice, permafrost, pingo, Spitsbergen, stable isotopes
\end{abstract}

\section{1 | INTRODUCTION}

In Earth's permafrost zone, groundwater freezing below the surface can result in the formation of large ice-cored perennial frost mounds called pingos. Upheaval of pingos is caused either by hydrostatic pressure in a hydrologically closed system, where aggrading permafrost encompasses water-rich sediments and expels water to the freezing front above, ${ }^{1}$ or by hydraulic pressure in a hydrologically open system where the pingo's massive ice core is fed continuously by a groundwater source. ${ }^{2}$ Both mechanisms result in accretion of a massive ice body composed of intrusive and/or segregation ice that heaves the surface up, forming conical elevations. Closed-system pingos are commonly associated with drained thermokarst lakes on flatlands. ${ }^{3}$ Open-system pingos occur in hilly and mountainous terrain, where relative elevation differences allow the hydraulic gradient to press water from ground aquifers into points of discharge and freezing. Thus, the latter are characteristic in mountain valleys of Spitsbergen ${ }^{4,5}$ where pingos are quite numerous. ${ }^{6}$

Spitsbergen is situated in the continuous permafrost zone and is characterized by glacier-covered mountains and trough-shaped 
valleys. A number of local pingos and the properties of their ice bodies have been studied by geophysical techniques, ${ }^{7-9}$ by chemical and physical investigations, ${ }^{9-11}$ and by stable-isotope analyses. ${ }^{9,12}$ The chemical composition of groundwater streams that have outlets at some pingos has been investigated. ${ }^{4,9,11-15}$

It is commonly acknowledged that the water feeding pingo ice in West Spitsbergen initially originates from below warm-based glaciers and moves under permanently frozen rocks via faults and fissures to points of discharge at lower parts of valleys. ${ }^{4,5,13}$ Pingo formation in the main Spitsbergen valleys probably initiated with the start of permafrost aggradation at around 3,000 years before the present (BP). ${ }^{16,17}$ Yoshikawa and Harada ${ }^{11}$ proposed three formation mechanisms for open-system pingos on Spitsbergen; pingos fed by subpermafrost groundwater along geologic faults (group I), pingos fed by artesian flow of migrating subglacial groundwater mainly in river valley positions (group II), and pingos which are found in nearshore environments of post-glacial isostatic uplift and are fed through small-scale discontinuities called "groundwater dikes" (group III).

The properties and positions of groundwater aquifers around Barentsburg and Grumantbyen were extensively studied by Russian (Soviet) deep drilling during coal exploration over the period 1931-1986. The data, which were first presented in 1983 by Kurkov and Neizvestnov ${ }^{18}$ and recently supplemented by new research and summarized by Demidov et al., ${ }^{19}$ allow three major types of aquifers to be distinguished for the Nordenskiöld Land Tertiary Basin on Spitsbergen.

The first type of aquifer is found in seasonal slope and river taliks and active layer groundwater flow. It is characterized by low mineralization (usually $0.03-0.6 \mathrm{~g} / \mathrm{L}$ ) and variable composition, commonly dominated by $\mathrm{Ca}^{2+}, \mathrm{Na}^{+}, \mathrm{Mg}^{2+}, \mathrm{SO}_{4}{ }^{2-}$ and $\mathrm{HCO}_{3}{ }^{-}$ions. ${ }^{19}$

The second type is represented by subpermafrost aquifers located within fault and fissure zones in upper geological strata (Paleogene and Cretaceous rocks) of the Nordenskiöld Land Tertiary Basin. ${ }^{19}$ Groundwater is characterized by relatively low mineralization ranging from 1 to $3.3 \mathrm{~g} / \mathrm{L}$ (up to $12 \mathrm{~g} / \mathrm{L}$ according to Kurkov and Neizvestnov ${ }^{18}$ ), and is dominated by $\mathrm{Na}^{+}$and $\mathrm{HCO}_{3}{ }^{-}$ions. These usually pressurized aquifers are encountered below permafrost and might be located both below and up to $100 \mathrm{~m}$ above the present sea level (asl). They might recharge via groundwater moving in fissures and faults under warm-based glaciers, ${ }^{19,20}$ by spring and summer precipitation filtering down from the surface through faults in the permafrost, ${ }^{18,21}$ and by water filtering from large lakes in the upper valleys (such as Lake Istjørna) that have enough area and depth to facilitate the existence of permanent taliks beneath them. ${ }^{19}$ Subglacial meltwater runoff feeding proglacial winter icings that are broadly spread on Spitsbergen can be classified as an intermediate between surface and subpermafrost aquifers. ${ }^{22}$

The third type is represented by sub- and intrapermafrost highly mineralized aquifers (30-35 g/L and higher) dominated by $\mathrm{Na}^{+}$and $\mathrm{Cl}^{-}$groundwater that can be considered to be of marine origin. Four subdivisions of this type can be distinguished in the Nordenskiöld Land Tertiary Basin based on age, positioning, and hydrology: (a) nearshore sea water aquifers, (b) residual Holocene cryopegs in marine terrace and valley sediments raised above sea level, (c) saline aquifers of Cretaceous-Paleogene strata, and (d) brine aquifers of deeply buried Triassic and lower, even older strata.

Nearshore saline aquifers are connected to present-day sea water that penetrates up to several kilometers inland via rock fissures, faults, coal layers, and deltaic deposits, and is pressurized exactly at sea level. Both sub- and intrapermafrost saline aquifers as well as level fluctuations following sea tides were registered in nearshore boreholes around Barentsburg. ${ }^{20}$

Residual Holocene transgression marine cryopegs have been found within Grøndalen Valley floor sediments above present sea level ${ }^{19}$ and could also occupy raised marine terraces. ${ }^{18}$

Cretaceous-Paleogene saline aquifers are buried more than $400 \mathrm{~m}$ below the surface in midland regions of the Tertiary basin and are found at shallower depths near the sea at Grønfjorden, Grumantbyen, and elsewhere on the edges of the basin ${ }^{18}$ following the dip of the geological strata. This groundwater has a typical marine ion composition and mineralization $(30-35 \mathrm{~g} / \mathrm{L})$, is pressurized at about sea level, and might be interconnected with the present-day sea via nearshore aquifers. ${ }^{19,20}$ However, the last of these was disputed after Barentsburg mine water inflow decreased during 19491980 drainage and aquifer funnel depletion, ${ }^{21}$ suggesting a stagnant regime of Cretaceous-Paleogene age groundwater. Relative positioning with sodium bicarbonate aquifers can be quite complex due to the nature of fault-dominated groundwater flow; the Nordenskiöld Land Tertiary Basin has been classified as cryoadartesian. ${ }^{19}$

Deeply buried Triassic (and lower strata) stagnant brine aquifers with mineralization of $\geq 35 \mathrm{~g} / \mathrm{L}$ are found below Jurassic lowpermeability shales. ${ }^{18,19}$

The focus of the present research is a group of pingos in Grøndalen Valley. Data for local aquifers were first obtained in 1926 when water from a perennial spring at the foot of one of the pingos (named Oin in Demidov et al. ${ }^{9}$ ) was sampled by A. K. Orvin. ${ }^{13}$ Samples were analysed by $\mathrm{G}$. Horn, revealing a mineralization of $0.88 \mathrm{~g} / \mathrm{L}$ with prevalent $\mathrm{Na}^{+}$and $\mathrm{HCO}_{3}{ }^{-}$ions. The same spring was sampled in 2018; analysis showed a mineralization of $1.19 \mathrm{~g} / \mathrm{L}$ dominated by bicarbonate. $^{9}$

Drilling and geophysical electrical resistivity measurements performed in 2020 at the riverbed in the lower part of Grøndalen Valley (borehole \#19 at $10 \mathrm{~m}$ asl) revealed the occurrence of cryopeg brine groundwater beneath frozen sand and gravel at 3-4 $\mathrm{m}$ below surface (bs), that is at $6 \mathrm{~m}$ asl. ${ }^{19}$ The brine had a mineralization of $43.5 \mathrm{~g} / \mathrm{L}$ (major ions $\mathrm{Na}^{+}$and $\mathrm{Cl}^{-}$) and a temperature of $-2.4^{\circ} \mathrm{C}$. Drilling of borehole \#18 at the Grøn River delta encountered a $0^{\circ} \mathrm{C}$ talik at $3 \mathrm{~m}$ bs ( $1 \mathrm{~m}$ below modern sea level) which most probably reflects the warming effect of present-day sea water and its infiltration into onshore deltaic deposits.

Data on Grøndalen Valley pingo formation were obtained by drilling six boreholes (\#8, \#9, \#13, \#15, \#18, \#19) with full coring on the mounds of the local Fili and Kili pingos (see Figure 1) and on a small pingo closer to the Grøn River delta (borehole \#8).

Borehole \#8-this borehole, drilled in 2017, was located $5 \mathrm{~m}$ to the side of the top of the pingo and did not encounter the bulk of the 
FIGURE 1 Overview map of study region in the Grøndalen Valley (redrawn after https:// toposvalbard.npolar.no) [Colour figure can be viewed at wileyonlinelibrary.com]
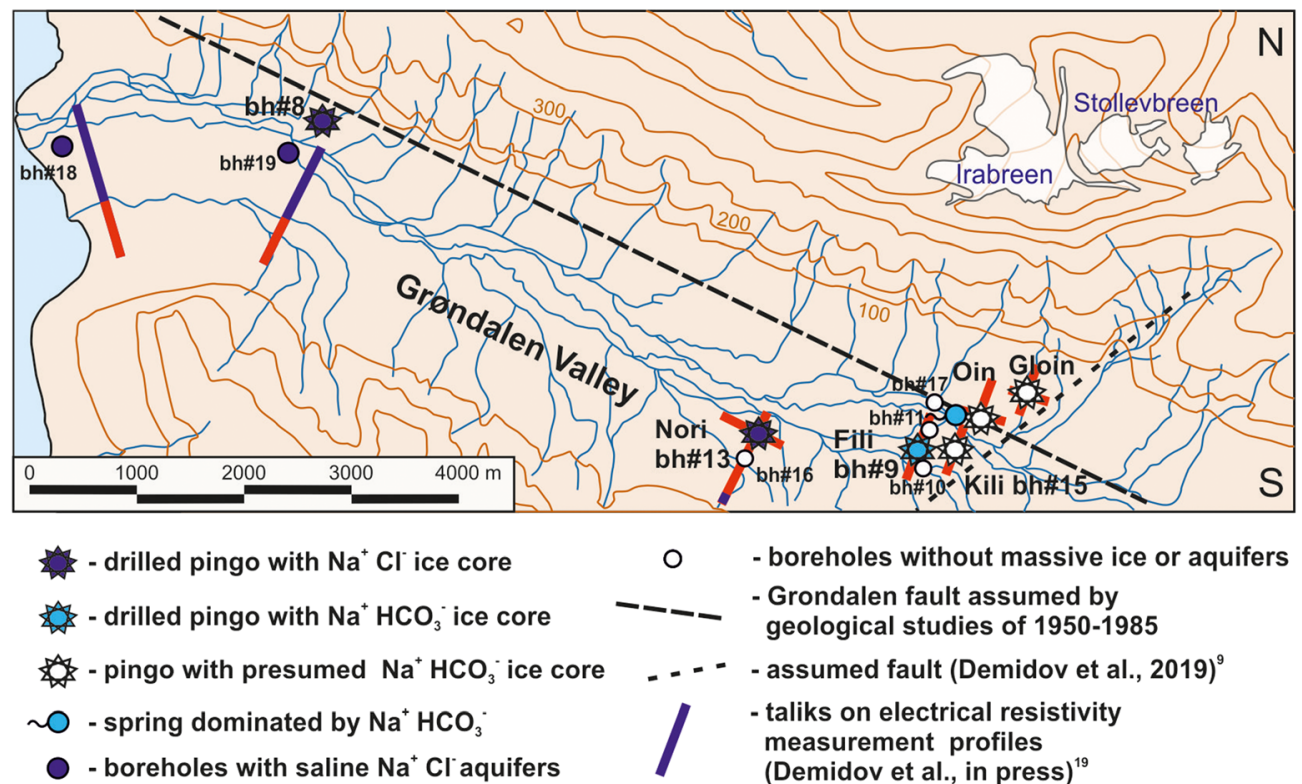

massive ice core. Salinity and ion content (dominated by $\mathrm{Na}^{+}$and $\mathrm{Cl}^{-}$) was measured for sediments and ice layers (the latter up to $1.5 \mathrm{~m}$ in thickness).

Borehole\# 9-full data for the 22.5-m Fili pingo ice core are available. ${ }^{9}$ The hydrochemical composition of the massive ice and permafrost below the Fili pingo and of sediments adjacent to its crater analysed from cores \#10, \#11, and \#15 is dominated by $\mathrm{Na}^{+}$and $\mathrm{HCO}_{3}{ }^{-}$ions (and to a lesser extent by $\mathrm{SO}_{4}{ }^{2-}$ ) similar to the perennial spring water at the foot of nearby Oin pingo, thus pointing to a terrestrial origin of the groundwater source feeding the Oin and Fili pingos and nonmarine conditions preceding freezing of the massive ice, which took long enough for $\mathrm{Cl}^{-}$salinity to disappear from sediments. $^{19}$

Borehole \#13-full data for the 16-m Nori pingo ice core dominated by $\mathrm{Na}^{+}$and $\mathrm{Cl}^{-}$are available (present paper).

Borehole \#15-data on Kili pingo ice core salinity and ion content were obtained in 2019 from just one sample taken from the upper apical layer of ice (13.7 m bs) where drilling was terminated. Sediments above the ice show a prevalence of $\mathrm{Na}^{+}$and $\mathrm{HCO}_{3}{ }^{-} / \mathrm{SO}_{4}{ }^{2-}$, while the ice is dominated by $\mathrm{Na}^{+}$and $\mathrm{Cl}^{-}$.

Borehole \#18-drilling undertaken in March 2020 to confirm electrical resistivity measurements encountered a talik at a temperature of $-0.25^{\circ} \mathrm{C}$ at $3 \mathrm{~m}$ bs and thawed sediments below.

Borehole \#19-the borehole drilled in March 2020 in the Grøn riverbed (10 $\mathrm{m}$ asl) through frozen gravel and sand deposits encountered a brine cryopeg aquifer (salinity $43.5 \mathrm{~g} / \mathrm{L}$ ) at $4 \mathrm{~m}$ bs (6 m asl). The water level stabilized at $3 \mathrm{~m}$ bs in $24 \mathrm{hr}$ and at $1.5 \mathrm{~m}$ bs in 7 days.

The detailed study of the Fili pingo (borehole \#9) comprised morphometric, cryolithologic, thermic, hydrochemical, and stable isotope analyses and revealed two episodes of closed-system freezing and two episodes of semiclosed freezing when the source water feeding the massive ice formation recharged. ${ }^{9}$ It was postulated that the Fili pingo ice was formed by water derived from warm-based glaciers.
This water moved to its discharge point in the valley through fault and fissure zones and froze and formed the pingo massive ice subsequently. ${ }^{9}$

The present study describes and discusses results of drilling with a full set of analyses of another pingo, Nori, that is $1.7 \mathrm{~km}$ from the Fili pingo, at a lower elevation in the valley (Figure 1). The study aims to determine major characteristics of the Nori pingo such as its internal structure, groundwater source, and geochemical and isotopic compositions to deduce distinct stages of pingo formation. An important task was comparing Nori's ice formation to that of the Fili pingo.

\section{2 | STUDY AREA}

The Grøndalen study area on the western coast of Nordenskiöld Land (Spitsbergen) is about $10 \mathrm{~km}$ southeast of Barentsburg, where the Russian Scientific Arctic Expedition on Spitsbergen Archipelago (RAE-S) maintains ground temperature and active-layer monitoring sites (Circumpolar Active Layer Monitoring, CALM) of the Global Terrestrial Network for Permafrost (GTN-P) program. ${ }^{23,24}$

The Grøndalen Valley is a trough valley cut into bedrock of Cretaceous-Paleogene shale and sandstone. ${ }^{25}$ Late Pleistocene and Holocene deposits in the lower part of the valley reach more than $20 \mathrm{~m}$ in thickness and probably represent sedimentation since at least the Last Glacial Maximum. ${ }^{26}$ The mountains surrounding the valley reach up to $700-800 \mathrm{~m}$ asl. The Tungebreen glacier and many streams, which collect meltwater discharge from small hanging glaciers on the valley sides, feed the Grøn River. Adjacent to the upper part of the valley are two larger glaciers, Tavlebreen and Passfjellbreen. The former is a warm-based glacier as seen in georadar studies. ${ }^{19,27}$ Istjørna Lake, which is positioned close to the upper part of Grøndalen Valley, might also serve as another source of groundwater recharge. 
Along the Grøndalen Valley between 13 and $60 \mathrm{~m}$ asl, five morphologically well-expressed large pingos (10-12.5 m high and 180-300 $\mathrm{m}$ in diameter) as well as several smaller, eroded pingos are present. The five large pingos are named after the dwarves of Scandinavian sagas and the works of J.R.R. Tolkien: Nori, Fili, Kili, Oin, and Gloin. ${ }^{9}$ The Nori pingo stands at the distal edge of a proluvial fan close to the Grøn River main channel. It has a regular spherical shape $120 \mathrm{~m}$ in diameter and $10.5 \mathrm{~m}$ high, from 32 to $42.5 \mathrm{~m}$ asl (Figure 2). Until now Grøndalen Valley pingos have been regarded, based on their positioning, as group III pingos, which formed in Holocene marine sediments shortly after sea regression. ${ }^{11}$

The meteorological station in Barentsburg (WMO station \#20107) at $75 \mathrm{~m}$ asl recorded a mean annual air temperature of $-2.2^{\circ} \mathrm{C}$ and mean annual precipitation of $704 \mathrm{~mm}$ for 2018. The ground temperatures measured by borehole thermistors in the area around Barentsburg at zero annual depth (11-40 m bs) range between -3.2 and $-2.4^{\circ} \mathrm{C}$ and the mean active layer thickness measured at the CALM site ( $3 \mathrm{~km}$ north of Barentsburg at $75 \mathrm{~m}$ asl) for 2017, 2018, and 2019 was 138, 144.5, and $133.5 \mathrm{~cm}$, respectively. ${ }^{19}$ The thickness of the permafrost zone in the Barentsburg area varies with morphology from $100 \mathrm{~m}$ near the seashore to $400-540 \mathrm{~m}$ in the mountain and upland areas. ${ }^{19}$ According to measurements in the central Grøndalen Valley, mean annual ground temperature is $-2.6^{\circ} \mathrm{C}$ at a depth of $14.25 \mathrm{~m}$ (borehole \#9). ${ }^{19}$ Thus, the permafrost thickness as estimated by the temperature gradient probably exceeds $100 \mathrm{~m}$ in the middle part of the valley.

\section{3 | MATERIALS AND METHODS}

\section{1 | Drilling and ground temperature measurements}

Drilling of the Nori pingo in April 2019 reached a depth of $21.8 \mathrm{~m}$ bs (core \#13, starting from $42.5 \mathrm{~m}$ asl, $77.99483^{\circ} \mathrm{N}, 14.59009^{\circ} \mathrm{E}$ ). The

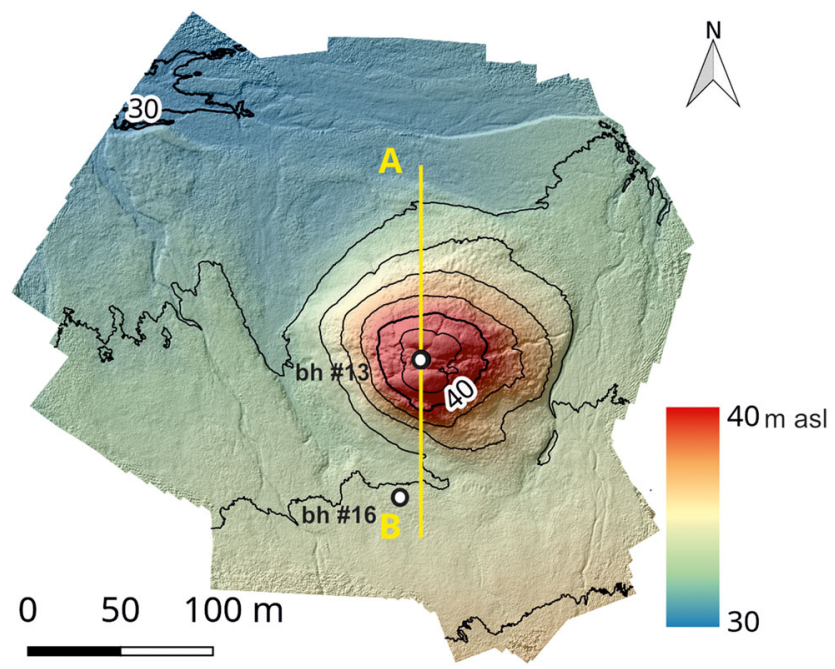

FIGURE 2 3D topographic model of the Nori pingo based on Demidov et al. ${ }^{19}$ The profile along the line A-B is shown in Figure 3 [Colour figure can be viewed at wileyonlinelibrary.com] core was obtained with a portable gasoline-powered rotary drilling rig (UKB 12/25, Vorovskiy Machine Factory, Ekaterinburg, Russia). The device uses no drilling fluid and relies on maintaining the frozen condition of the core for stratigraphic integrity and to prevent downhole contamination of the biogenic and sedimentological characteristics of the core. Drill diameters were $112 \mathrm{~mm}$ for the upper part and $76 \mathrm{~mm}$ for the lower part. The core pieces were lifted to the surface every $30-50 \mathrm{~cm}$. After documentation and cryolithological description, ${ }^{28}$ core pieces were sealed in ziplock bags. Ice samples were kept frozen for transportation while sediment samples were kept unfrozen. Continuous temperature measurements on Nori pingo were established on April 15, 2019 by installing a 15-m-long Geo Precision logger chain (M-Log5W cable) equipped with sensors every $0.75 \mathrm{~m}$.

In March 2020, an additional borehole, \#16, was drilled at the foot of the Nori pingo down to $7 \mathrm{~m}$ bs through gravel and silt deposits, and three further boreholes (\#17, \#18, \#19) were drilled in the Grøn River bed using the same equipment and sampling approaches as described above.

\section{2 | Stable water isotopes}

Ice samples for the stable water isotope analyses were taken every $30-50 \mathrm{~cm}$ along the core. The stable water isotope composition $\left(\delta^{18} \mathrm{O}\right.$ and $\delta D$ ) of massive pingo ice was analyzed at the Climate and Environmental Research Laboratory (CERL, Arctic and Antarctic Research Institute, St. Petersburg, Russia) using a Picarro L2120-i analyzer. After every five samples the working standard (SPB-2, $\delta^{18} \mathrm{O}=-9.66 \%$ and $\delta \mathrm{D}=-74.1 \%$ ) was measured. SPB-2 is made of distilled St. Petersburg tap water and is calibrated against the International Atomic Energy Agency (IAEA) standards VSMOW-2 (Vienna Standard Mean Ocean Water 2), GISP (Greenland Ice Sheet Precipitation), and SLAP-2 (Standard Light Antarctic Precipitation 2). The reproducibility of the results is $0.08 \%$ for $\delta^{18} \mathrm{O}$ and $0.4 \%$ for $\delta \mathrm{D}$ and was assessed by remeasuring a random selection of $10 \%$ of the total samples. The measurement error is thus one or two orders of magnitude less than the natural isotopic variability of pingo ice, which is satisfactory for the purpose of this study. The $\delta^{18} \mathrm{O}$ and $\delta \mathrm{D}$ values are given as per mil (\%) difference to the VSMOW-2 standard. The deuterium excess $(d)$ is calculated as $d=\delta \mathrm{D}-8 \delta^{18} \mathrm{O} .^{29}$

\section{3 | Hydrochemistry}

Sediment and ice samples for ion content analyses were taken every $30-50 \mathrm{~cm}$. The ion content of sedimentary permafrost samples from core \#13 of the Nori pingo was estimated after water extraction at the analytical laboratory of RAE-S, Barentsburg. The material was dried and sieved at $1 \mathrm{~mm}$. About $20 \mathrm{~g}$ of the sediment was suspended in $100 \mathrm{ml}$ of de-ionized water and filtered through a $0.45-\mu \mathrm{m}$ nylon mesh within $3 \mathrm{~min}$ after stirring. Electrical conductivity (EC, measured in $\mu \mathrm{S} / \mathrm{cm}$ ) and $\mathrm{pH}$ values were estimated with a Mettler Toledo Seven Compact S 220. EC values were transformed automatically by the 
instrument into general ion content (mineralization) values given as $\mathrm{mg} / \mathrm{L}$.

Major anions and cations in the water extracts were analyzed by ion chromatography (Shimadzu LC-20 Prominence) equipped with the Shimadzu CDD-10AVp conductometric detector and ion exchange columns for anions (Transgenomic ICSep AN2) and for cations (Shodex ICYS-50). Calibrations were performed in two sensitivity

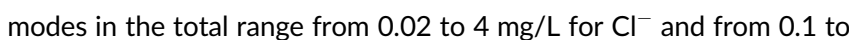
$20 \mathrm{mg} / \mathrm{L}$ for $\mathrm{SO}_{4}{ }^{2-}, \mathrm{Na}^{+}, \mathrm{K}^{+}, \mathrm{Ca}^{+}$, and $\mathrm{Mg}^{+}$. The quantification limit was $0.02 \mathrm{mg} / \mathrm{L}$ for $\mathrm{Cl}^{-}$and $0.1 \mathrm{mg} / \mathrm{L}_{\text {for }} \mathrm{SO}_{4}{ }^{2-}$ and for cations, while precision errors were between $5 \%$ (for the concentration range 0.1 $4 \mathrm{mg} / \mathrm{L} \mathrm{Cl}^{-}, 5-20 \mathrm{mg} / \mathrm{L} \mathrm{SO}_{4}{ }^{2-}$, and 2-20 mg/ $\mathrm{L} \mathrm{Na}^{+}, \mathrm{K}^{+}, \mathrm{Ca}^{+}, \mathrm{Mg}^{+}$) to $15 \%$ (for the concentration range $0.02-0.1 \mathrm{mg} / \mathrm{L} \mathrm{Cl}^{-}, 0.1-5 \mathrm{mg} / \mathrm{L}$ $\mathrm{SO}_{4}{ }^{2-}$, and 2-20 mg/L Na${ }^{+}, \mathrm{K}^{+}, \mathrm{Ca}^{+}, \mathrm{Mg}^{+}$).

The bicarbonate concentration was calculated directly from inorganic carbon content measured by a Shimadzu TOC-L analyzer. Samples were treated with $\mathrm{HCl}$ and subjected to a sparging process and infrared detecting in a TOC-L infrared gas analyser (NDIR) with a detection limit of $4 \mu \mathrm{g} / \mathrm{L}$. The contribution of carbonates and dissolved $\mathrm{CO}_{2}$ to inorganic carbon content was considered negligible based on $\mathrm{pH}$ measurement results. The quantification limit for inorganic carbon was $0.1 \mathrm{mg} / \mathrm{L}$, and the precision error did not exceed $\pm 6 \%$.

Melted pingo ice samples from core \#13 and spring water samples were analyzed after filtration through $0.45-\mu \mathrm{m}$ nylon mesh on the same equipment using the same techniques for $\mathrm{pH}, \mathrm{EC}$, and ion composition as for sedimentary permafrost samples.

\section{4 | Ice crystallography}

Horizontally oriented thin ice lenses were sampled from the core for the study of the Nori pingo massive ice with intervals of about 1-1.5 m. Standard crystal-optical techniques were used for analysis. ${ }^{30}$ The texture of the ice, the size of inclusions, and the nature of inclusion distribution were examined in transmitted light on ice plates with a thickness of $>1 \mathrm{~cm}$. The structural characteristics of the ice crystals were studied using a system of polaroids and a polarizing binocular microscope. To prepare a thin section, samples were cleaned with fine sandpaper and polished on two sides on a heated metal plate. The brightest picture was observed in sections $<1 \mathrm{~mm}$ thick. Subsequently, the sizes, shapes, and spatial relationships of the ice crystals were studied. The orientation of the optical axes was determined approximately by the number of crystals in the section with different interference colors.

\section{4 | RESULTS}

The $21.8 \mathrm{~m}$ long core \#13 drilled from the Nori pingo top exposed cover and basal sedimentary horizons enclosing the massive pingo ice (Figure 3). From 0 to $4.4 \mathrm{~m}$ bs, gravelly layers with small pebbles, loam, and sand (up to 40 vol\% estimated) were found containing pore ice. From 4.4 to $20.5 \mathrm{~m}$ bs (corresponding to 38.1 to $22 \mathrm{~m}$ asl), transparent massive ice was observed. The massive ice body was dissected by a gravel layer at $17-18 \mathrm{~m}$ bs. Down to $8.5 \mathrm{~m}$ bs the ice was transparent.

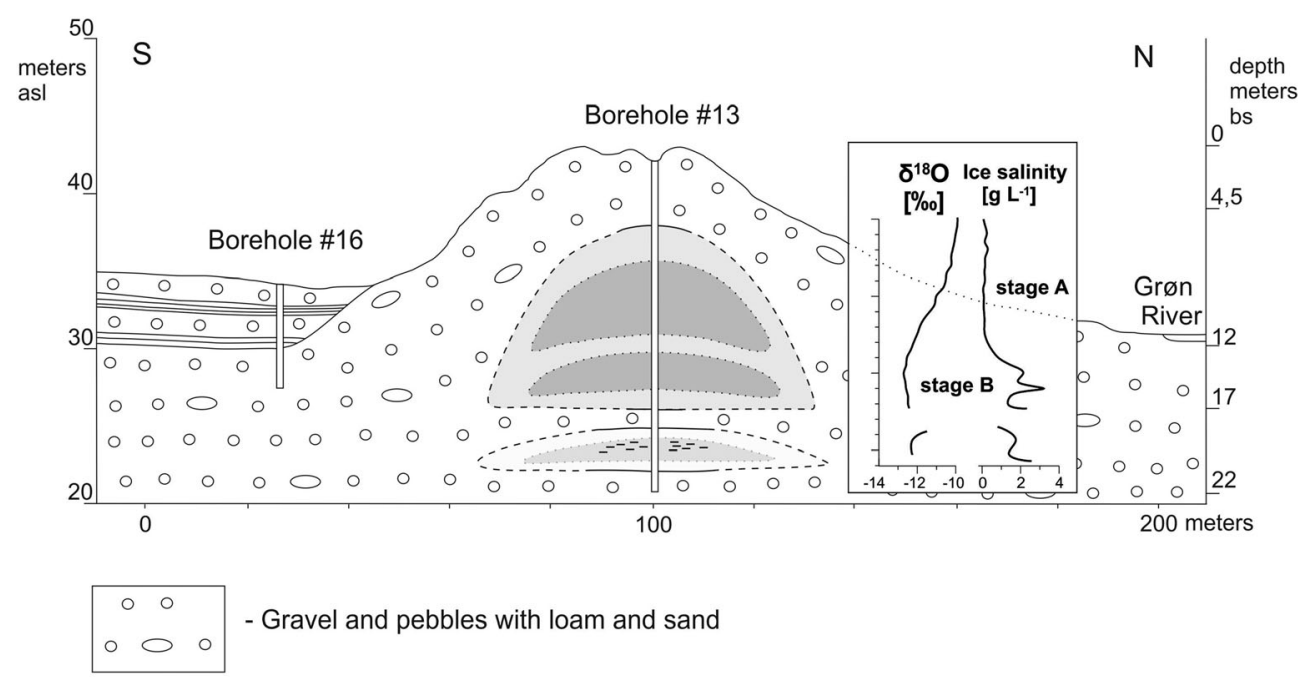

FIGURE 3 Profile across the Nori pingo based on drilling data
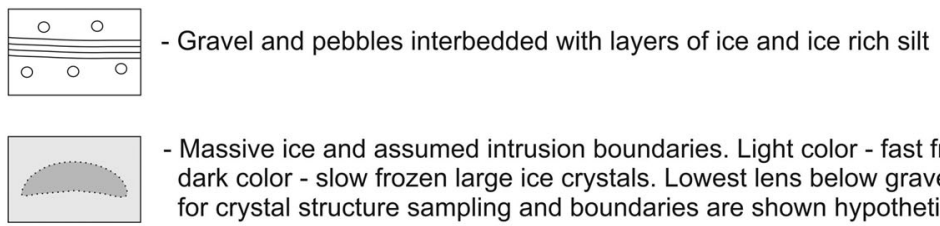

- Massive ice and assumed intrusion boundaries. Light color - fast frozen small ice crystals, dark color - slow frozen large ice crystals. Lowest lens below gravel layer was unavailable for crystal structure sampling and boundaries are shown hypothetically

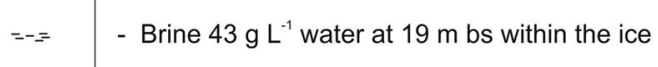


It contained silty inclusions (flakes, 1-3 mm) and a small number of gas bubbles ( $\varnothing$ 1-2 mm). From 8.5 to $14.5 \mathrm{~m}$ bs, the ice was clear and transparent with up to 20 vol\% of subvertically oriented bubbles. From 14.5 to $17.0 \mathrm{~m}$ bs, the ice was clear, transparent, and almost free of bubbles. From 18 to $20.5 \mathrm{~m}$, the ice was free of bubbles but less transparent, and colored by silty inclusions. At a drill depth of $19 \mathrm{~m}$ bs, several tens of liters of salty water $\left(43 \mathrm{~g} / \mathrm{L} / \mathrm{L}\right.$, predominately $\mathrm{Na}^{+}$ and $\mathrm{Cl}^{-}$) appeared in the borehole and remained there unfrozen for 2 days until fully scooped out before the drilling continued deeper. A sample of this water was analyzed for ion content but stable water isotopes were not measured. Below the massive ice at a depth of 20.5-21.8 m bs, frozen gravel with rare pebbles and loam (up to 30 vol\% estimated) was encountered containing pore ice.

Temperature measured by a stationary thermistor at $14.25 \mathrm{~m}$ depth within the massive pingo ice varied between -2.93 and $-2.56^{\circ} \mathrm{C}$ (from April 2019 to April 2020) with mean annual ground temperature of $-2.80^{\circ} \mathrm{C}$.

\section{1 | Isotopic and hydrochemical properties of massive pingo ice and of enclosing sediments}

Based on the cryolithological and geochemical properties of core \#13 (Figure 4, Table 1), the retrieved sequence can be differentiated into four units, which are described in detail below: cover sediment (0-4.4 $\mathrm{m}$ bs), massive pingo ice, stage $A$ (4.4-14 $\mathrm{m}$ bs), massive pingo ice, stage $B$ (14-21 m bs), and basal sediment (21-21.8 m bs).

The cover sediment (0-4.4 $\mathrm{m}$ bs) shows a slight increase with depth in the overall very low ion content of the sedimentary water extracts, from 0 to $0.4 \mathrm{~g} / \mathrm{L}$ (mean $0.1 \mathrm{~g} / \mathrm{L}$ ). Dominating ions of the hydrochemical composition are $\mathrm{Na}^{+}$(mean $58 \mathrm{mg} / \mathrm{L}$ ) and $\mathrm{Cl}^{-}(24 \mathrm{mg} /$ L) although the latter shows a variable pattern with depth. Between 0.8 and $1.6 \mathrm{~m} \mathrm{bs} \mathrm{Na}{ }^{+}$and $\mathrm{HCO}_{3}{ }^{-}$ions dominate. The $\mathrm{pH}$ in pore ice of the cover sediment is neutral with a mean value of 6.9 .

The massive pingo ice stage A between 4.4 and $14 \mathrm{~m}$ bs is characterized by low ion content ranging from 0.1 to $0.3 \mathrm{~g} / \mathrm{L}$, increasing steeply on the boundary with stage B to $0.8 \mathrm{~g} / \mathrm{L}$. The major ions are $\mathrm{Na}^{+}$(mean $192 \mathrm{mg} / \mathrm{L}$ ) and $\mathrm{Cl}^{-}$(mean $72 \mathrm{mg} / \mathrm{L}$ ). The $\mathrm{pH}$ is alkaline and shows a generally decreasing trend with depth (mean 8.4). The stable water isotope composition shows a downcore decreasing trend from -9.9 to $-12.5 \%$ in $\delta^{18} \mathrm{O}$ and from -74 to $-91 \%$ o in $\delta \mathrm{D}$, while $d$ increases with depth from 5 to $8 \%$. The freezing of pingo ice is seen in $\delta^{18} O-\delta D$ and $\delta D-d$ slopes of 6.7 and -0.2 , respectively (Figure 5 ).

The lower part of the Nori pingo ice between 14 and $21 \mathrm{~m}$ bs, representing stage $B$, is characterized by a steep rise in ion content reaching up to $3.2 \mathrm{~g} / \mathrm{L}$ at $15.5 \mathrm{~m}$ bs. This ice includes a sedimentary layer at 17-18 $\mathrm{m}$ bs. The massive pingo ice above and below this sedimentary layer shows a mean ion content about 10 times higher than in stage $\mathrm{A}, 1.9 \mathrm{~g} / \mathrm{L}$, and is dominated by $\mathrm{Na}^{+}$(mean $810 \mathrm{mg} / \mathrm{L}$ ) and $\mathrm{Cl}^{-}$(mean $963 \mathrm{mg} / \mathrm{L}$ ) ions. The two water extract data points of the sedimentary layer within stage $\mathrm{B}$ exhibit lower concentrations of $\mathrm{Na}^{+}$ and $\mathrm{Cl}^{-}$, while $\mathrm{Ca}^{2+}$ and $\mathrm{Mg}^{2+}$ as well as $\mathrm{HCO}_{3}{ }^{-}$and $\mathrm{SO}_{4}{ }^{2-}$ contents are higher than in the massive ice samples directly above and below the sedimentary layer. The mean ion content from the water extract data is $1.0 \mathrm{~g} / \mathrm{L}$. The mean $\mathrm{pH}$ values of the massive ice and the sedimentary layer samples of stage B reach 7.3 and 8.3 , respectively. The stable water isotope composition of stage B pingo ice shows little

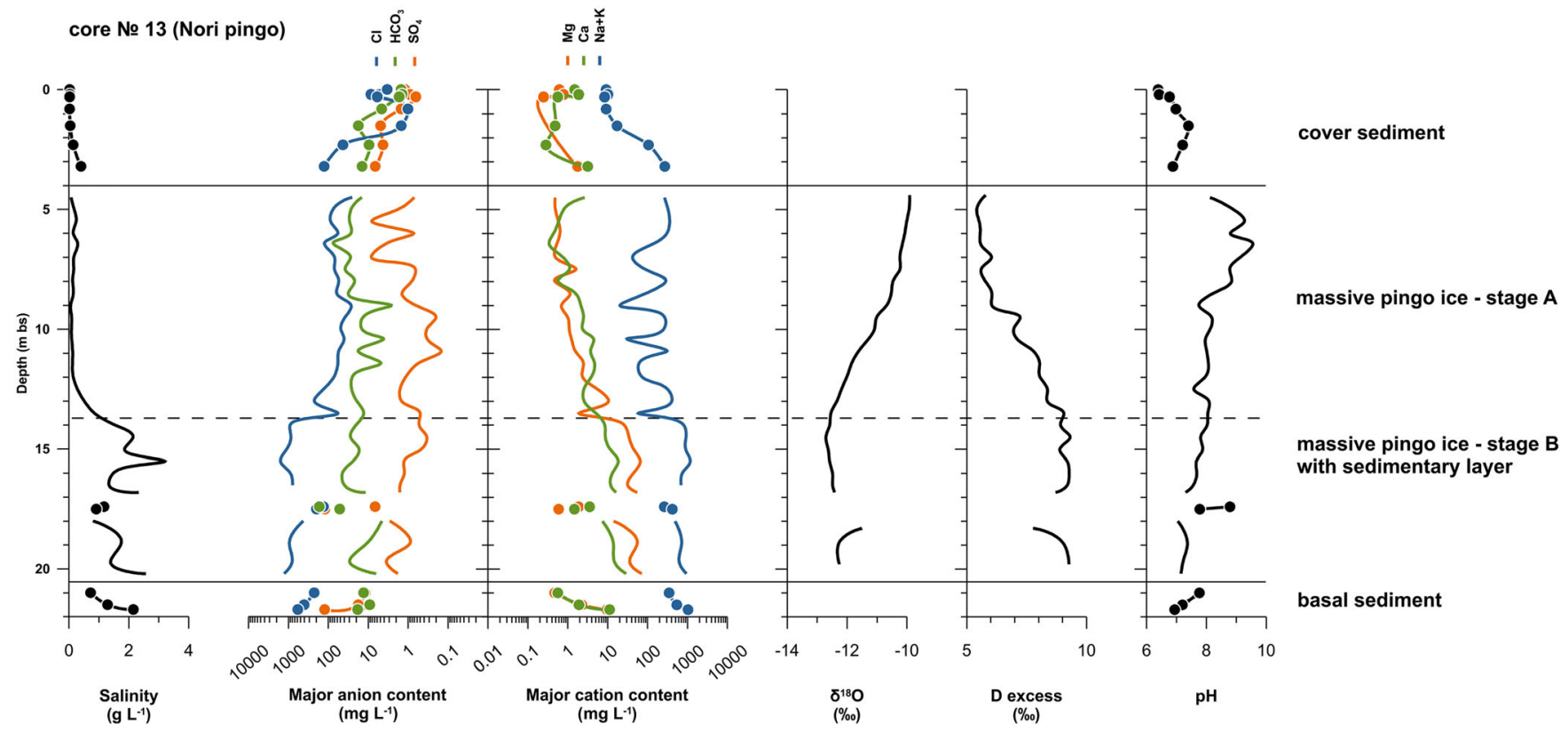

FIGURE 4 Stable water isotope and hydrochemical data (note that values from sedimentary water extracts of the cover and basal sediment as well as of the sediment layer within stage B are shown as dots) [Colour figure can be viewed at wileyonlinelibrary.com] 
TAB LE 1 Stable isotope $\left(\delta^{18} \mathrm{O}, \delta \mathrm{D}\right.$, and $\left.d\right)$ and hydrochemical composition of core \#13 of the Nori pingo given as minimum-maximum values and mean \pm standard deviation values. Additionally, slopes, intercept, and correlation coefficient $\left(r^{2}\right)$ of $\delta^{18} O-\delta D$ and $\delta D-d$ plots are given. Data are shown in Figures 4 and 5. n/a, not analyzed

\begin{tabular}{|c|c|c|c|c|c|c|}
\hline & & Cover sediment & Pingo ice stage $A$ & Pingo ice stage $B$ & Sedimentary layer stage B & Basal sediment \\
\hline Core depth & [m bs] & $0-4.4$ & $4.4-14$ & $14-21$ & $17-18$ & $21-21.8$ \\
\hline$n$ & & 7 & 19 & 11 & 2 & 3 \\
\hline$\delta^{18} \mathrm{O}$ mean & {$[\%$ ] } & $\mathrm{n} / \mathrm{a}$ & $-10.95 \pm 0.89$ & $-12.39 \pm 0.35$ & $\mathrm{n} / \mathrm{a}$ & $\mathrm{n} / \mathrm{a}$ \\
\hline$\delta \mathrm{D} \min -\max$ & {$[\% \circ]$} & $\mathrm{n} / \mathrm{a}$ & -91.3 to -73.5 & -92.4 to -84.3 & $\mathrm{n} / \mathrm{a}$ & $\mathrm{n} / \mathrm{a}$ \\
\hline$d$ min-max & [\%o] & $\mathrm{n} / \mathrm{a}$ & 5.4 to 9.1 & 7.8 to 9.3 & $\mathrm{n} / \mathrm{a}$ & $n / a$ \\
\hline$d$ mean & [\%o] & $\mathrm{n} / \mathrm{a}$ & $6.7 \pm 1.2$ & $9.0 \pm 0.5$ & $n / a$ & $n / a$ \\
\hline Slope & $\delta^{18} \mathrm{O}-\delta \mathrm{D}$ & $\mathrm{n} / \mathrm{a}$ & 6.68 & 6.89 & $\mathrm{n} / \mathrm{a}$ & $\mathrm{n} / \mathrm{a}$ \\
\hline Intercept & $\delta^{18} \mathrm{O}-\delta \mathrm{D}$ & $\mathrm{n} / \mathrm{a}$ & -7.74 & -4.82 & $n / a$ & $\mathrm{n} / \mathrm{a}$ \\
\hline$r^{2}$ & $\delta^{18} \mathrm{O}-\delta \mathrm{D}$ & $\mathrm{n} / \mathrm{a}$ & 1 & 0.99 & $n / a$ & $\mathrm{n} / \mathrm{a}$ \\
\hline $\mathrm{pH} \min -\max$ & & $6.4-7.4$ & $7.6-9.6$ & $7.8-8.3$ & $7.8-8.8$ & $6.9-7.8$ \\
\hline $\mathrm{pH}$ mean & & $6.9 \pm 0.4$ & $8.4 \pm 0.5$ & $7.5 \pm 0.3$ & $8.3 \pm 0.7$ & $7.3 \pm 0.4$ \\
\hline EC min-max & {$[\mu \mathrm{S} / \mathrm{cm}]$} & $24-724$ & $115-1,695$ & $4-5,300$ & $1,616-2,090$ & $1,326-3,680$ \\
\hline EC mean & {$[\mu \mathrm{S} / \mathrm{cm}]$} & $172 \pm 258$ & $383 \pm 372$ & $3,018 \pm 1,387$ & $1,853 \pm 335$ & $2,422 \pm 1,185$ \\
\hline Ion content min-max & {$[g / L]$} & $0-0.4$ & $0.1-0.8$ & $0.8-3.2$ & $0.9-1.2$ & $0.7-2.2$ \\
\hline Ion content mean & {$[g / L]$} & $0.1 \pm 0.1$ & $0.2 \pm 0.2$ & $1.9 \pm 0.7$ & $1.0 \pm 0.2$ & $1.4 \pm 0.7$ \\
\hline $\mathrm{Na}^{+} \min -\max$ & {$[\mathrm{mg} / \mathrm{L}]$} & $3.8-264.6$ & $18.2-403.2$ & $479.3-1164.9$ & $257.8-406.6$ & $344.5-1012.0$ \\
\hline $\mathrm{Na}^{+}$mean & {$[\mathrm{mg} / \mathrm{L}]$} & $58.3 \pm 97.9$ & $191.7 \pm 130.5$ & $801.1 \pm 185.2$ & $332.2 \pm 105.2$ & $630.0 \pm 344.0$ \\
\hline $\mathrm{Cl}^{-} \min -\max$ & {$[\mathrm{mg} / \mathrm{L}]$} & $1.0-128.1$ & $25.3-223.2$ & $423.2-1596.0$ & $132.5-199.5$ & $226.8-584.5$ \\
\hline $\mathrm{Cl}^{-}$mean & {$[\mathrm{mg} / \mathrm{L}]$} & $24.4 \pm 46.8$ & $72.2 \pm 45.8$ & $962.6 \pm 313.9$ & $166.0 \pm 47.4$ & $405.8 \pm 178.9$ \\
\hline $\mathrm{SO}_{4}^{2-} \min -\max$ & {$[\mathrm{mg} / \mathrm{L}]$} & $0.6-6.7$ & $0.1-8.4$ & $0.3-3.5$ & $6.7-123.1$ & $12.0-124.5$ \\
\hline $\mathrm{SO}_{4}{ }^{2-}$ mean & {$[\mathrm{mg} / \mathrm{L}]$} & $2.9 \pm 2.4$ & $1.7 \pm 2.4$ & $1.5 \pm 1.0$ & $64.9 \pm 82.3$ & $51.4 \pm 63.4$ \\
\hline $\mathrm{HCO}_{3}{ }^{-} \min -\max$ & {$[\mathrm{mg} / \mathrm{L}]$} & $1.4-17.8$ & $2.6-76.1$ & $4-6-44.7$ & $52.2-168.7$ & $9.2-18.4$ \\
\hline $\mathrm{HCO}_{3}{ }^{-}$mean & {$[\mathrm{mg} / \mathrm{L}]$} & $7.3 \pm 6.7$ & $22.7 \pm 16.2$ & $21.5 \pm 13.2$ & $110.5 \pm 82.3$ & $13.6 \pm 4.6$ \\
\hline
\end{tabular}

variation, with values of around $-12.5 \%$ in $\delta^{18} \mathrm{O},-91 \%$ in $\delta \mathrm{D}$, and $9 \%$ in $d$ except for one data point directly below the sedimentary layer. Here, less depleted values of $-11.5 \%$ in $\delta^{18} \mathrm{O},-4 \%$ in $\delta \mathrm{D}$, and $9 \%$ in $d$ are noted.

The basal sediment underlying the massive pingo ice was sampled at depths from 21 to $21.8 \mathrm{~m}$ bs. The hydrochemical composition of sedimentary water extracts shows increasing ion content with depth from 0.7 to $2.2 \mathrm{mg} / \mathrm{L}$ (mean $1.4 \mathrm{mg} / \mathrm{L}$ ) and a dominance of $\mathrm{Na}^{+}$and $\mathrm{Cl}^{-}$ions. The $\mathrm{pH}$ decreases with depth from 7.8 to 6.9 .

\section{2 | Ice structure}

Nine ice samples for structure analyses were obtained starting from the upper boundary of the massive ice of stage A down to the gravel layer within stage B (Figure 6, Table 2). Most of the Nori pingo massive ice has an allotriamorphic-granular structure with large crystal sizes of more than 1-2 cm, sometimes exceeding $7 \mathrm{~cm}$. The crystals have irregular shapes and the optical orientation is random. Thus, the ice formed with no possibility of orthotropic crystallization. This 

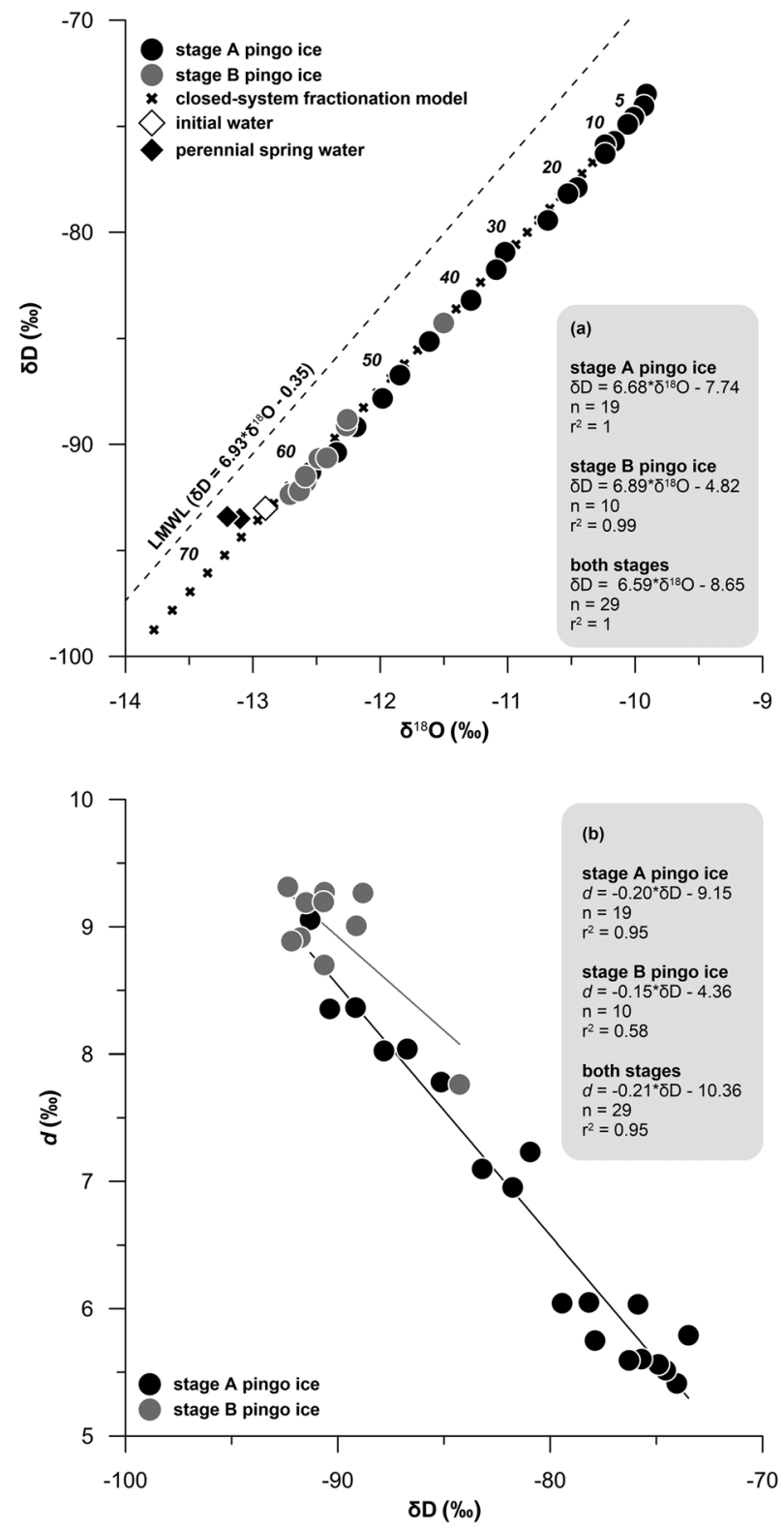

FIGURE 5 Co-isotopic plots of the Nori pingo massive ice stages $A$ and $B$ (note values from 5 to 70 on the fractionation model show percentage of frozen water lens volume; see Figure 7)

indicates injections of large water volumes under subsequent slow freezing conditions. Notable exceptions are three layers of fast frozen ice at core depths of 4.6-4.7 m bs, 12.0-12.1 m bs (encompassing stage A), and 16.8-17.0 $\mathrm{m}$ bs (immediately above the gravel layer within stage $B$ ) where we observe small crystals (2-15 mm).

\section{5 | DISCUSSION}

\section{1 | Properties and formation dynamics of the Nori pingo massive ice}

The $4.4 \mathrm{~m}$ thickness of frozen sediments overlying the Nori pingo massive ice shows the minimum extent of ground freezing before the massive ice core formed, accounting for possible erosion on top of the pingo cone after it heaved. Pingo ice grows with groundwater supply from below, resulting in ice layers of different ages. The upper apical layers of the ice were formed first and are underlain by younger ice of subsequent generations. ${ }^{1,2}$ The isotopic and hydrochemical stratification of the Nori pingo massive ice clearly indicates two formation stages. The earlier stage $\mathrm{A}$ of pingo growth is represented by low mineralized $\mathrm{Na}^{+}$- and $\mathrm{Cl}^{-}$-dominated ice that was unearthed between 4.4 and $14 \mathrm{~m}$ bs. The down-core strong decline of $2.6 \%$ in $\delta^{18} \mathrm{O}$ and $17 \%$ in $\delta \mathrm{D}$, accompanied by a $d$ increase of $3 \%$ (Figure 4), indicates a high near-surface temperature gradient and isotopically closed-system freezing that is also seen in the upper part (unit I) and further in the lower part (unit III) of the Fili pingo massive ice. ${ }^{9}$ A rapid change in the isotopic and geochemical compositions of the Nori pingo massive ice is observed at the border with stage $B$. The mineralization rises steeply as compared to stage $A$, but the dominance of $\mathrm{Na}^{+}$and $\mathrm{Cl}^{-}$ions is maintained. The stage $\mathrm{B}$ ice shows little isotopic variation with values of around $-12.5 \%$ in $\delta^{18} \mathrm{O},-91 \%$ in $\delta \mathrm{D}$, and $9 \%$ in $d$ (Figures 4 and 5), which is characteristic for freezing in an isotopically semi-open system with a supply of additional water. An alternative explanation of the stage $B$ isotopic trend is a higher rate of freezing in a closed system. However, the latter explanation seems less feasible than a semi-open system because the temperature gradient in general must become less steep with depth and observed ice freezing rates in other closed-system pingos clearly show a decreasing isotopic pattern down-core. ${ }^{31}$ Furthermore, the down-core isotopic trend in stage B shows not only a leveling off, but also a slight reversal of values which would be impossible in closed-system freezing. However, the low sampling resolution of only three samples representing the lower stage B ice below the gravel layer somewhat hampers differentiating this as a single stage.

The observed threshold between stages $A$ and $B$ in mineralization is remarkably sharp and cannot be explained solely by a gradual trend such as down-core salt expulsion during freezing. An understanding of this threshold may be obtained by the study of ice structures. The structure of ice crystals in different layers of the Nori pingo massive ice shows several shifts down-core from fast to slow freezing that reflect a series of injections (Table 2). Stage $A$ is characterized by slowly frozen thick injection ice (samples from 7.3 to $10.6 \mathrm{~m}$ bs) encompassed by thinner layers of fast frozen ice on the upper and lower boundaries. Fast frozen ice layers mark the start of pingo growth and the transition to stage $B$ massive injection (Figure 3). The upper apical layer was formed at an early stage of pingo formation, when the permafrost was still thin and the freezing rate was faster. Lower fast frozen layers mark episodes of water injections under fast freezing conditions and arguably into cracks and fissures of the already existing ice body. The massive injection ice of stage $B$ is found above the gravel layer (samples from 13.5 to $15.3 \mathrm{~m} \mathrm{bs}$ ) and is encompassed by fast frozen ice layers on the upper boundary (with stage A) and lower boundary (with the gravel layer). Samples for structure analyses from below the gravel layer, where 3-m-thick massive ice was observed, were unavailable because the quality of the fractured core material was poor, and the amount was limited due to the 

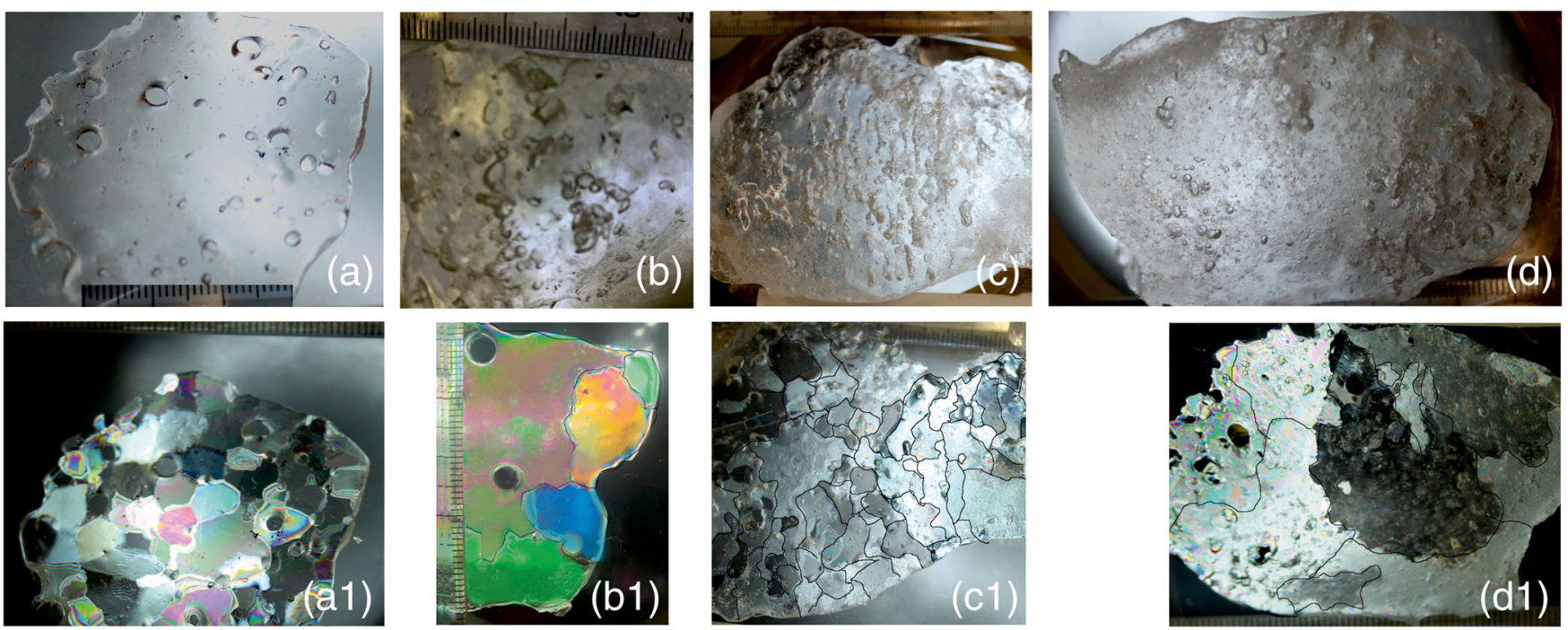

FIGURE 6 Nori pingo massive ice structures, crystal size and orientation of stage A ice at 4.6-4.7 m bs (a, a1), at 10.5-10.6 m bs (b, b1), at 12.0-12.1 $\mathrm{m}$ bs (c, c1), and of stage B ice at 15.2-15.3 $\mathrm{m}$ bs (d, d1). Samples were oriented horizontally in the core [Colour figure can be viewed at wileyonlinelibrary.com]

TABLE 2 Nori pingo core \#13 ice structure

\begin{tabular}{|c|c|c|c|}
\hline $\begin{array}{l}\text { Sample depth } \\
\text { ( } \mathrm{m} \text { bs) }\end{array}$ & $\begin{array}{l}\text { Crystal size }(\mathrm{mm}) \text {, form, optical } \\
\text { orientation }\end{array}$ & Gas bubbles & Interpretation \\
\hline $4.6-4.7$ & $\begin{array}{l}\text { 2-4, irregular form, chaotic } \\
\text { orientation }\end{array}$ & Rare bubbles & $\begin{array}{l}\text { Apical part of ice body grows when } \\
\text { permafrost thickness is low and freezing } \\
\text { rate is significant }\end{array}$ \\
\hline $5.7-5.8$ & $\begin{array}{l}5-30 \text {, irregular form, chaotic } \\
\text { orientation }\end{array}$ & $\begin{array}{l}\text { Medium content, oblate bubbles }(\varnothing 2- \\
3 \mathrm{~mm} \text { ) }\end{array}$ & $\begin{array}{l}\text { Increase in pressure during freezing with } \\
\text { slowing rate }\end{array}$ \\
\hline $8.9-8.95$ & $\begin{array}{l}>70 \text {, irregular form, chaotic } \\
\text { orientation }\end{array}$ & $\begin{array}{l}\text { Many spherical bubbles ( } \varnothing 4-5 \mathrm{~mm}) \\
\text { grouped in chains and nests }\end{array}$ & \multirow{2}{*}{$\begin{array}{l}\text { Freezing of large portions of injected water } \\
\text { under slow heat flux }\end{array}$} \\
\hline $10.5-10.6$ & $\begin{array}{l}>70, \text { irregular form, chaotic } \\
\text { orientation }\end{array}$ & $\begin{array}{l}\text { Many spherical bubbles ( } \varnothing 4-5 \mathrm{~mm}) \\
\text { grouped in chains and nests }\end{array}$ & \\
\hline $15.2-15.3$ & $\begin{array}{l}>70 \text {, irregular form, chaotic } \\
\text { orientation }\end{array}$ & $\begin{array}{l}\text { Many spherical bubbles ( } \varnothing 1-3 \mathrm{~mm}) \\
\text { grouped in chains and nests }\end{array}$ & $\begin{array}{l}\text { Freezing of large portions of injected water } \\
\text { under slow heat flux }\end{array}$ \\
\hline $16.8-17.0$ & $\begin{array}{l}2-10 \text {, irregular form, chaotic } \\
\text { orientation }\end{array}$ & High content, $30 \%$ of ice volume & $\begin{array}{l}\text { Fast freezing of injected water in dynamic } \\
\text { conditions }\end{array}$ \\
\hline
\end{tabular}

smaller drill diameter at these drill depths. However, based on the sequence listed above it can be assumed that the ice from below the gravel layer also consists of a large injection of slowly frozen massive ice, which is probably encompassed by fast frozen ice layers.

Overall, the structure of Nori pingo massive ice provides evidence of several injection cycles of large water volumes. Each injection cycle, as outlined above, corresponds to one of the determined stages of pingo formation. The volume and timing of each cycle depended on local geological, temperature, climatic, and hydrological fluctuations that are impossible to reconstruct in detail. They do not resemble (at least among available selected crystallographic core samples) the thinner and much more numerous cycles of seasonal growth bands that were described for the Tuktoyaktuk pingo 20 by Mackay. ${ }^{32}$ This might be explained by thicker sediment cover above the Nori pingo massive ice compared to the Tuktoyaktuk pingo 20 that led to a lower amplitude of seasonal ground temperature within the forming ice. The 
data obtained from Nori pingo massive ice point to just large injections during the period of pingo growth with each injection forming a pressurized lens under the massive core cap where it subsequently slowly froze. Fast frozen ice in between slowly frozen ice lenses may represent either smaller scale separate injections or parts of large injections that appeared close to the lens boundary where the temperature gradient appeared to be the largest. The presence of the gravel layer at $17-18 \mathrm{~m}$ bs in the geometrical center of Nori pingo is hard to explain from classical single-stage hydraulic/hydrostatic pingo massive ice growth dynamics. Therefore, in Figure 3 the gravel layer is shown hypothetically dividing the massive ice into two separate lenses, as a stage of intermediate freezing of a talik during stage B formation with a third water injection underneath. However, it is equally possible that the 1-m-thick gravel layer is in fact partly enclosed by the massive ice of stage $B$ due to temporary dislocation of a water lens away from the center of the pingo, as was described for the Tuktoyaktuk pingo $20 .{ }^{32}$

\section{2 | Groundwater source of the Nori pingo massive ice}

Nori pingo is the only pingo in Spitsbergen where a full core of saline ice is encountered. It is important to determine the groundwater source of saline ice. Below we discuss possibilities that different aquifers served as sources for the Nori pingo massive ice accretion.

Based on chemical and isotopic properties the Nori pingo massive ice can be clearly divided into two parts: an upper, earlier formed stage $A$ and a lower, later formed stage $B$. Both parts are dominated by $\mathrm{Na}^{+}$and $\mathrm{Cl}^{-}$ions with stage $\mathrm{B}$ having much higher mineralization than stage $A$. The ice mineralization in stage $B$ peaks at $3.2 \mathrm{~g} / \mathrm{L}$, corresponding to sea ice salinity which ranges between 2 and $20 \mathrm{~g} /$ $\mathrm{L}^{33,34}$ The down-core ion composition shows different trends in major anions. $\mathrm{SO}_{4}{ }^{2-}$ and $\mathrm{HCO}_{3}{ }^{-}$contens remain low and relatively stable throughout the core; it is solely the rise of $\mathrm{Cl}^{-}$content (accompanied by $\mathrm{Na}^{+}$) that is responsible for the stage $\mathrm{B}$ mineralization jump. The ice mineralization could have been influenced to an unknown extent by salt migration down-core. Similarly, saline water with mineralization of $43 \mathrm{~g} / \mathrm{L}$ that was found within the stage B massive ice below the gravel layer during drilling should not be understood as a property of the initial source unaffected by cryogenic expulsion. Regardless, it is clear that the source water for pingo formation was dominated by $\mathrm{Na}^{+}$and $\mathrm{Cl}^{-}$ions.

While Triassic saline and brine aquifers are presumably too deep to reach the surface, saline Cretaceous-Paleogene aquifers that are closer to the surface might be considered to be a source for Nori pingo formation. The necessary condition is that the CretaceousPaleogene aquifers' interconnection with the sea basin is indeed negligible and the regime is stagnant. In this case either permafrost aggradation or gas pockmark flow could result in expulsion of saline groundwater above its initial level (which tends to approach sea level over the long term). The possibility of pingo formation due to permafrost aggradation that goes deep into the valley sediments encompassing large areas, thus expelling groundwater upward at certain points of discharge, was demonstrated by modeling for the Adventdalen Valley. ${ }^{35}$ Ground temperature measurements in the central Grøndalen Valley show permafrost reaching at least $100 \mathrm{~m}$ bs. Therefore, it is possible that local isolated Cretaceous-Paleogene saline aquifers could indeed be subject to cryogenic pressure. The obstacle to this explanation of the pingo ice source is the absence of present-day saline springs in Grøndalen Valley. This also rules out the idea of gas upwelling. While pockmarks on the sea floor in the area of a major fault zone in Grønfjorden were in fact detected by geophysical sensing, ${ }^{36}$ only a sodium bicarbonate stream is now observed in Grøndalen Valley with no sign of sodium and chloride outflow.

To explain the possibility of sodium and chloride groundwater being pushed above sea level some analogues can be found on Spitsbergen. The group of Trollosen springs is situated on the southern tip of the island at Stormbukta. The water discharge fluctuates similarly with local glacier-fed rivers and the largest spring (discharge of $10 \mathrm{~m}^{3}$ / s) has a temperature of $+4^{\circ} \mathrm{C}$. $^{4}$ The spring emerges from limestone karst rocks near a large glacier network. The water is typically of grayish-green color, indicating its glacial origin. ${ }^{36}$ Adjacent smaller springs with water temperatures reaching $10-11^{\circ} \mathrm{C}$ have been sampled and show a mineralization of $4.8 \mathrm{~g} / \mathrm{L}$, high gas content (mostly $\mathrm{N}_{2}$ and $\mathrm{CO}_{2}$ ), and a dominance of sodium and chloride ions. ${ }^{4,37}$ While Liestol $^{4}$ proposed a mixed origin of the springs with seawater leaking into the system, Postnov ${ }^{37}$ considered it to have been derived from saline Triassic aquifers. Thermal gas-rich saline sodium- and chloridedominated high-temperature springs are also known from Bockfjorden. ${ }^{37}$

Mixing of water from pressurized sodium bicarbonate aquifers with lower lying sea water aquifers, akin to the mechanism proposed by Liestol $^{4}$ for Trollosen springs, was recently suggested for Adventdalen Valley springs. ${ }^{35}$ The Adventdalen Valley springs produced contradictory hydrochemical data. Measurement results differed substantially from year to year. ${ }^{4,11,13,15}$ The most recent data on four Adventdalen pingo streams have revealed the dominance of sodium bicarbonate water in all of them. Chloride content rose with more inland positions, with the strongest chloride admixture found in those pingos that stand in the upper part of the Adventdalen Valley, the Innerhytte and Riverbed pingos. ${ }^{15}$ The two latter pingos stand at or slightly above the local level of Holocene transgression (65 and $77 \mathrm{~m}$ asl respectively) on a fault zone ${ }^{38}$ and it seems highly unlikely that the chloride content is as noticeable as it is due to sea water admixture as proposed by Hornum et al. ${ }^{35}$ Instead, it could be explained as being characteristic of local terrestrial bicarbonate groundwater in which a substantial chloride admixture is not unusual, as chloride in general is second in concentration after bicarbonate in this type of groundwater. ${ }^{19}$ Yet the idea that pressurized sodium bicarbonate groundwater can mix with saline aquifers resulting in sodium- and chloride-dominated flow generating the hydraulic pressure necessary to form a pingo cannot be excluded from the range of possible explanations.

The Nori pingo is positioned on the valley floor at $32 \mathrm{~m}$ asl, well within the local boundary of the Holocene transgression that reached 
$70 \mathrm{~m}$ asl. ${ }^{39}$ As seen by electrical resistivity measurements and data from borehole \#18, sediments in the Grøn River Delta are still saturated by seawater. Past similar seawater intrusions could have provided the $\mathrm{NaCl}$ content of the Nori pingo massive ice. Yet it is unlikely that groundwater with immediate hydraulic connection to the adjacent sea could allow pingo hydraulic/hydrostatic upheaval above sea level without any additional forces contributing. It is more likely to expect this from an isolated seawater cryopeg lens that forced pingo growth in closed-system conditions. Data from electrical resistivity measurements and hydrochemical properties of water from borehole $\# 19^{19}$ give evidence of present-day brine cryopegs dominated by $\mathrm{NaCl}$ (with salinity exceeding that of seawater) in the lower part of Grøndalen Valley. We consider the most likely origin of these aquifers to be residual seawater, which was preserved as isolated cryopeg lenses in late Quaternary loose deposits after the early and middle Holocene transgressions. The cryopeg salinity rose substantially during permafrost aggradation and salt expulsion, as is characteristic for cryopegs across the Arctic. ${ }^{40}$ The Nori pingo is situated only $4.5 \mathrm{~km}$ from borehole \#19 where cryopeg water was encountered (Figure 1). The similar geomorphological position and ion composition point to cryopeg water as a possible source for the Nori pingo massive ice. While marine cryopeg freezing is indeed capable of forming massive underground ice underlain by residual brine aquifers as reported from the Yamal Peninsula, ${ }^{41}$ there is an ambiguity in this explanation for the formation of the Nori pingo. If a residual Holocene cryopeg was the only source of the Nori pingo massive ice, the pressure necessary for upheaval could be obtained only in closed-system conditions when the cryopeg lens became isolated within encompassing permafrost, with subsequent rise of hydrostatic pressure and freezing of the limited amount of saline groundwater at the point of discharge (i.e., the pingo mound). This mechanism, however, would not freeze the whole amount of saline groundwater completely due to insufficiently low local ground temperatures. Freezing of water of marine salinity starts at $-1.8^{\circ} \mathrm{C}$. At $-5^{\circ} \mathrm{C}, 40 \%$ of the water with a mineralization of $80 \mathrm{~g} / \mathrm{L}$ remains unfrozen. This water would only freeze completely at $-36^{\circ} \mathrm{C}$, reaching a mineralization of $250 \mathrm{~g} / \mathrm{L} .{ }^{40}$ Neither observed temperatures within Nori borehole \#13 nor electrical resistivity measurements support this scenario. Deposits underlying Nori's ice core are now frozen; their lowest recorded temperature is $-2.93^{\circ} \mathrm{C}$. This temperature would leave in place the largest amount of saline cryopeg water (far exceeding the mass of the massive ice), unfrozen and pressurized beneath the ice. Such a substantial talik has not been found by electrical resistivity measurements adjacent to Nori pingo. ${ }^{19}$ The drainage of cryopeg brine into rock fissures or due to a river talik forming near this location at some time in the past might be considered as a way to explain its disappearance, but this remains a hypothesis only.

As already mentioned, there is no clear basis for concluding that any saline aquifers found in Nordenskiöld Land could have been a direct source for the Nori pingo ice accretion. Nori pingo is positioned in a mountain valley at the edge of a proluvial fan without any visible remnant morphological features of a drained lake. A hydrostatic closed-system origin of the pingo seems unlikely from a geomorphological point of view. Therefore, we exclude the hypothesis that the groundwater froze completely within enclosing permafrost, and that initial lake evaporation resulted in the isotopic rise of source water. At the same time, Nori's isotopic trend in stage B reflects the inflow of a new portion of groundwater, which points to a hydraulic source. This is in accordance with earlier expectations for Spitsbergen open-type mountain valley pingos. ${ }^{4}$ In the case of Nori pingo, its ice formation can best be described as semi-open type (periodically open) which is characterized by dynamic groundwater flow, with an unknown amount passing out of the system when isotopically lighter water escapes back into the source aquifer, remains as residual water trapped within the ice, or drains into a temporary pingo spring. Therefore, it is impossible to determine Nori's source water by calculating the mean value of ice core isotopic content as proposed for hydrostatic closed-system pingos (where $100 \%$ of water freezes out). ${ }^{31,32,42}$ Instead, our calculation is based on the model by Ekaykin et al. ${ }^{43}$; this model utilizes the isotopic trend in ideal closed-system freezing and compares it with the stage $A$ trend (Figure 7).
FIGURE 7 Modeling of stable water isotope fractionation during water freezing in a closed system (stage A) Short-dashed lines are the modeled isotopic content $\left(\delta^{18} \mathrm{O}\right.$ in blue and deuterium excess in green) of the new portions of ice as a function of the fraction of frozen water for the initial water isotopic composition of $-12.9 \%$ o for $\delta^{18} \mathrm{O}$ and $-93 \%$ for $\delta \mathrm{D}$. Solid lines are the isotopic content $\left(\delta^{18} \mathrm{O}\right.$ in blue and deuterium excess in green) of stage $A$ of the Nori pingo. Long-dashed lines show the confidence intervals ( $\pm 2 \mathrm{~s}$ ) of the stage $A$ isotopic values [Colour figure can be viewed at wileyonlinelibrary.com]

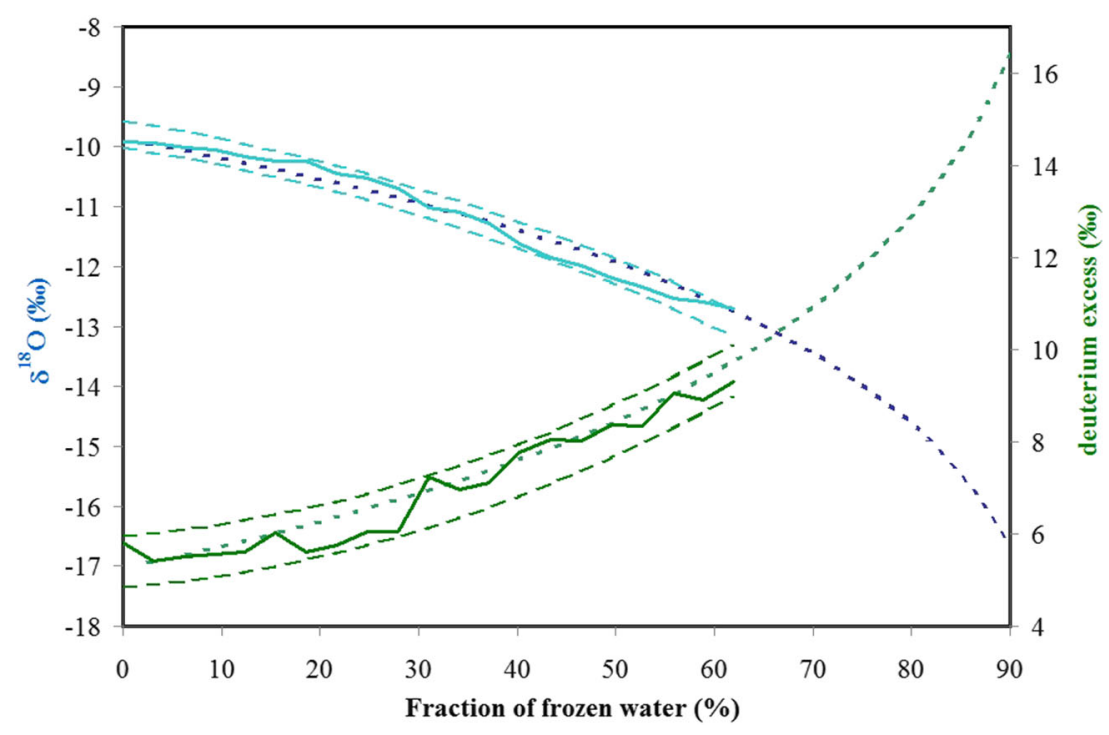


At the start of accretion, the massive ice had $-9.91 \%$ in $\delta^{18} \mathrm{O}$, $-73.5 \%$ in $\delta \mathrm{D}$, and 5.8 in $d$ (sample at $4.4 \mathrm{~m} \mathrm{bs}$ ). According to the model this corresponds to $-12.9 \%$ in $\delta^{18} \mathrm{O},-93 \%$ in $\delta \mathrm{D}$, and 10.2 in $d$ in source water. Such an isotopic content is much lower than in local meteoric waters (lakes, rivers, and glacier meltwater) where $\delta^{18} \mathrm{O}$ ranges from -11 to $-10 \%$ and $\delta \mathrm{D}$ from -77 to $-70 \%,{ }^{44}$ and drastically lower than in sea water, which indicates that any seasonal talik or any saline aquifer unaffected by cryogenic concentration cannot be a source for Nori's ice. Cryopeg water might exhibit low isotopic values, as confirmed by earlier studies. ${ }^{45}$ However, our model shows that seawater freezing leads to $-13 \%$ in $\delta^{18} \mathrm{O},-87 \%$ in $\delta \mathrm{D}$, and $17 \%$ in $d$, which is very different from what we see in Nori's water source. Instead, its initial isotopic content calculated by the proposed model is surprisingly close to the isotopic content of the nearby Oin pingo perennial spring, which was measured at $-13.1 \%$ in $\delta^{18} \mathrm{O}$ and $-93.5 \%$ in $\delta \mathrm{D}$ in spring $2018^{9}$ and $-13.2 \%$ in $\delta^{18} \mathrm{O}$ and $-93.4 \%$ in $\delta D$ in September 2019. The only difference between Nori's water source and the spring is the geochemical composition (the spring is dominated by bicarbonate).

It seems reasonable to conclude that the similarity between the isotopic content of the Oin pingo spring and the modeled Nori pingo groundwater source is not a coincidence and that all Grøndalen pingos had a similar source in the form of a local bicarbonate-dominated Paleogene strata pressurized aquifer that is the source of the Oin pingo outflow. Sodium and chloride ions that enrich Nori pingo ice must have appeared in its source when initial low-mineralization bicarbonate groundwater filtered through residually saline marine sediments on the way to the pingo. There was no other noticeable groundwater admixture and consequently the isotopic content did not change. For some reason residual marine salinity in sediments, as seen by sampling around the Grøndalen pingos, ${ }^{19}$ was preserved only in the lower part of the valley (cores \#13 and \#8) while pingos formed in the upper part of the valley are situated in sediments where no marine salinity was preserved (cores \#10, \#11, and \#15). ${ }^{19}$

The unusually low isotopic property of Paleogene strata bicarbonate groundwater observed in pingo spring and ice can be explained as having been derived from warm-based glacier ice of cold epochs (from snow that presumably accumulated during the late Holocene) that melted into subpermafrost aquifers. Alternatively, this could be explained by prolonged cryoconcentration that ancient freely circulating groundwater of Spitsbergen underwent after it became trapped under permafrost at the start of climate cooling and permafrost aggradation. ${ }^{18}$

According to the proposed model, the isotopic trend in Nori's massive ice that changed during stage $B$ from depletion to stability and even to slight reversal reflects additional inflow (new intrusion) of pressurized groundwater under the pingo. According to our isotope model, ${ }^{43}$ during closed conditions in stage $A$ (i.e., the first intrusion was temporarily isolated from the source) $62 \%$ of the initial $-12.9 \%$ in $\delta^{18} \mathrm{O}$ and $-93 \%$ in $\delta \mathrm{D}$ water volume froze, resulting in the remaining water being depleted in isotopes down to $-15.8 \%$ in $\delta^{18} \mathrm{O}$ and $-111 \%$ in $\delta \mathrm{D}$. The slight reversal of isotopic values seen in stage $\mathrm{B}$ cannot be explained by a change in freezing rate. The reversal must have been due to new intrusion of water in stage $B$ with isotopic values of $-12.9 \%$ in $\delta^{18} \mathrm{O}$ and $-93 \%$ in $\delta \mathrm{D}$. This water flowed into the subpingo water lens (supplying roughly $50 \%$ of the total lens volume) and compensated for the depletion trend, leading to the observed relatively stable and slightly reversed stage B ice isotopic pattern down-core.

Slow freezing of the stage $A$ water lens resulted in thorough salt expulsion and low mineralization of the stage $A$ ice. However, stage $B$ freezing, which occurred under similar slow freezing conditions as shown by the crystal structure, resulted in much higher mineralization of the ice. This is difficult to explain based on the semi-open freezing model. Yet it is clear that salt expelled from stage $A$ ice must have been incorporated into later stage ice and some of it was left in brine water (i.e., brine encountered at $19 \mathrm{~m}$ bs) because permafrost temperatures were not low enough for complete freezing of the $\mathrm{NaCl}$ solution. Higher mineralization in stage $\mathrm{B}$ might be explained by the process of freezing liquid water pockets captured in the ice as was found by drilling of Antarctic Lake Vostok ${ }^{46}$ accompanied by later salt migration down-core. Due to the frozen state of sediments and the absence of a water lens below the Nori pingo at present and no sign of spring outflow, it can be postulated that the process of ice accretion stopped at some time in the past and the Nori pingo is now inactive.

\section{3 | Comparison to available data of other Spitsbergen pingos}

The history of the $\mathrm{NaCl}$-dominated Nori pingo massive ice formation differs from the Fili pingo, where the massive ice core was formed completely from $\mathrm{NaHCO}_{3}$-dominated groundwater. ${ }^{9}$ The Fili pingo stands $1.7 \mathrm{~km}$ up the valley from the Nori pingo with its feet at $45 \mathrm{~m}$ asl so both pingos stand within the limit of local Holocene transgression. To deduce the paleogeographic conditions of the two nearby pingos, Holocene transgression dynamics and climate-permafrost interaction need to be considered. Local sea level in an area around Grøndalen Valley dropped to lower than $30 \mathrm{~m}$ asl around 9,600 years BP as suggested by a study of the nearby Linnevatnet Lake. ${ }^{47}$ Sea level became lower than present around 6,500 years BP as suggested by radiocarbon dating of the Grønfjorden marine terraces and underwater abrasion cliffs observed at $10 \mathrm{~m}$ below sea level. ${ }^{39}$ Therefore, the Grøndalen Valley floor was dry during most of the Holocene except for the time needed for deltaic-type filling of the fjord, analogous to the process described for Adventdalen Valley by Gilbert. ${ }^{48}$ Temperatures from the start of the Holocene until 4,000 years BP were about $2^{\circ} \mathrm{C}$ higher than present, ${ }^{49}$ which suggests that conditions for continuous permafrost and pingo formation were unfavorable. Permafrost aggradation and pingo growth in central Spitsbergen valleys probably began only around 3,000 years $\mathrm{BP}^{16,17}$ after the climate shifted from the early Holocene optimum ${ }^{50,51}$ to late Holocene cooling. Therefore, it would be reasonable to assume that both Nori and Fili pingos started forming simultaneously around 3,000 years BP on the already dry Grøndalen Valley floor. This growth was caused by 
hydraulic flow (that changed, in stages, from a closed to a semi-open mechanism) of low mineralization $\mathrm{NaHCO}_{3}$ groundwater of a local Paleogene strata aquifer supplied via an adjacent fault.

The difference between the Nori and Fili pingos was the conditions of sediments around them. Fili pingo, being more distant from the sea and positioned $13 \mathrm{~m}$ higher above sea level than Nori pingo, apparently had no residual salinity left in the surrounding gravel and silt strata and its massive ice inherited the $\mathrm{Na}^{+}$and $\mathrm{HCO}_{3}{ }^{-}$content of the groundwater source. The Nori pingo, which stands at a lower elevation, formed in sediments enriched by residual salinity. This salinity was absorbed by groundwater resulting in accretion of saline ice.

While the chemical composition of Nori and Fili pingo ice is different, the isotopic and mineralization trends are similar. These similarities are particularly seen in the upper stage $A$ of massive ice growth (upper $9.6 \mathrm{~m}$ ) in Nori pingo and the upper $8.4 \mathrm{~m}$ of massive ice (Unit 1) in Fili pingo. ${ }^{9}$ The upper stages of both pingos are characterized by low mineralization accompanied by a closed-system-type isotopic depletion and similar initial isotopic values. Down-core, both Nori and Fili pingo ice exhibit an increase in mineralization and a new isotopic pattern. Similarities in ice core isotopic and chemical trends point to similar mechanisms and conditions of formation. The difference remains in the groundwater chemistry. While saline Nori ice received a sizable influx of $\mathrm{Cl}^{-}$and $\mathrm{Na}^{+}$ions down-core, Fili ice exhibits a less sharp increase in mineralization in its lower part, which is mainly due to $\mathrm{HCO}_{3}{ }^{-}$and $\mathrm{Na}^{+}$ions and, to a lesser extent, to $\mathrm{Cl}^{-}$.

These two pingos in lower and upper parts of the same valley have different $\mathrm{NaCl}$ and $\mathrm{NaHCO}_{3}$ groundwater sources. We assume this to be characteristic for other pingos of Nordenskiöld Land. This view is supported by available data. Saline $\mathrm{NaCl}$ domination is revealed in pingos in lower parts of valleys, in the Nori pingo ice core, and in ice layers in a small pingo drilled by borehole \#8, at elevations of 32 and $13 \mathrm{~m}$ asl, respectively, in Grøndalen Valley, and in Lagoon pingo spring (positioned in the Adventdalen delta at $2 \mathrm{~m}$ asl) as measured by Yoshikawa and Harada. ${ }^{11} \mathrm{NaHCO}_{3}$ content is found in upper parts of valleys, in the Fili pingo ice core and adjacent Oin pingo spring in Grøndalen Valley at an elevation of $45 \mathrm{~m}$ asl, in two Reindalen Valley pingo springs at elevations of $122 \mathrm{~m}$ asl (Ny pingo) and $35 \mathrm{~m}$ asl (Kjuklingtoppane/Riperfjellbreen), ${ }^{19}$ and in Adventdalen pingo springs at elevations of $2 \mathrm{~m}$ asl (Lagoon pingo as per 2016-2017 measurements), $20 \mathrm{~m}$ asl (Førstehytte pingo), $65 \mathrm{~m}$ asl (Janssonhaugen pingo), and $77 \mathrm{~m}$ asl (Riverbed pingo). ${ }^{15}$ It was previously suggested that the majority of Nordenskiöld Land pingos were formed by pressurized $\mathrm{NaHCO}_{3}$ subpermafrost groundwater. ${ }^{19}$ The results of the Nori pingo drilling support this view, with the addition that $\mathrm{NaCl}$ enrichment becomes possible in marine sediments in lower parts of the Nordenskiöld Land valleys.

\section{6 | CONCLUSIONS}

Drilling of a 21.8-m-deep borehole \#13 on top of the 10.5-m-high Nori pingo that stands at $32 \mathrm{~m}$ asl in Grøndalen Valley revealed a core of massive ice $16.1 \mathrm{~m}$ thick. The retrieved sequence is differentiated into four units: the frozen cover of gravelly sediment (0-4.4 m bs); massive pingo ice, stage $A$ (4.4-14 $\mathrm{m}$ bs); massive pingo ice, stage $B$ (14-21 m bs) intersected by a gravel layer at 17-18 m; and the basal gravelly frozen sediment (21-21.8 $\mathrm{m}$ bs). Despite the frozen state of sediments above and beneath the ice core some tens of liters of saline $\mathrm{Cl}^{-}$and $\mathrm{Na}^{+}$water at negative temperature was found below the gravel layer within stage $B$ ice and extracted during drilling. Its mineralization of $43 \mathrm{~g} / \mathrm{L}$ was very close to that of the groundwater observed in a cryopeg $4.5 \mathrm{~km}$ lower in the valley drilled by borehole \#19. Mean annual temperatures at a depth of $14.25 \mathrm{~m}$ below the top of the pingo reach $-2.8^{\circ} \mathrm{C}$. Sediments below the Nori pingo ice core are frozen and no spring has been observed to emerge near the mound, which makes it clear that the pingo is now inactive.

Geochemical analyses of the massive pingo ice and of water extracts of the enclosing sediments shows a prevalence of $\mathrm{Na}^{+}$and $\mathrm{Cl}^{-}$throughout the core, with massive ice of stage $\mathrm{B}$ having a mineralization multiple times higher than that of stage $A$. The stable water isotope record of the pingo ice shows two different trends. The stable water isotope composition of stage $A$, which reflects an early stage of pingo ice formation, shows a closed-system down-core decreasing trend in $\delta^{18} \mathrm{O}$ and $\delta \mathrm{D}$, while $d$ increases. The stable water isotope composition of stage $B$ pingo ice shows a trend of a semi-open system with one slight reversal and overall little variation.

The Nori pingo ice core down to $17 \mathrm{~m}$ bs consists of two massive lenses of allotriamorphic-granular structure ice with large crystals, more than 1-2 cm and sometimes more than $7 \mathrm{~cm}$ in diameter, with irregular shape and random crystallographic orientation, indicating injections of large masses of water under conditions of subsequent slow freezing. The upper lens corresponds to stage $A$ and the lower lens to stage $B$. The boundaries between each lens are characterized by samples of fast frozen ice where we observe small crystals (2-15 mm) and a distribution of medium-sized gas bubbles, relatively smaller or larger than usual. Overall, the structure of Nori's ice core suggests several intrusion cycles of large quantities of saline $\mathrm{NaCl}$ groundwater under the pingo; each cycle consisted of initial fast freezing on the boundary, then slow freezing of the main bulk of the injected water.

The isotopic properties of the initial groundwater source $\left(-12.9 \%\right.$ in $\delta^{18} \mathrm{O},-93 \%$ in $\delta \mathrm{D}$, and 10.2 in $\left.d\right)$ modeled on stage $\mathrm{A}$ ice (oldest values $-9.91 \%$ o in $\delta^{18} \mathrm{O},-73.5 \%$ in $\delta \mathrm{D}$, and 5.8 in $d$ in the sample at $4.4 \mathrm{~m}$ bs) are substantially depleted compared to modern meteoric waters and drastically depleted if compared to seawater. However, the values are almost identical to those of the perennial $\mathrm{NaHCO}_{3}$ spring at the foot of nearby Oin pingo. The analysis of local aquifers leads to the conclusion that the Nori pingo was sourced hydraulically, by a mechanism that changed, in stages, from a closed to a semi-open system, through a local fault zone by $\mathrm{NaHCO}_{3}$ groundwater of a Paleogene strata aquifer with low mineralization that became enriched in sodium and chloride ions while filtering through the valley sediments with residual marine salinity.

The comparison between $\mathrm{NaCl}$-dominated Nori pingo ice and $\mathrm{NaHCO}_{3}$ ice of the earlier drilled adjacent Fili pingo may serve as an 
indicator for groundwater source patterns of other Nordenskiöld Land pingos. The major source for their formation is $\mathrm{NaHCO}_{3}$ groundwater from fault and fissure aquifers. A majority of pingos, especially those standing higher up the valleys above the maximum level of Holocene transgression, have $\mathrm{NaHCO}_{3}$ massive ice, while those pingos located in lower valleys have $\mathrm{NaCl}$-dominated ice due to groundwater being enriched by the residual salinity of valley sediments, as is the case with Nori pingo investigated here.

\section{AUTHOR CONTRIBUTIONS}

V.D. and N.D. initiated and designed the present study. They further drilled and documented the cores. A.E., A.V., and A.K. carried out stable isotope analyses. L.S. and S.V. supported the overall data analysis and interpretation. A.T. provided 3D modeling of the pingo. A.K. analyzed electrical resistivity measurements. V.G. analysed the structural properties of the ice cores. V.D. and S.W. wrote the paper with input from all other co-authors, who contributed equally to the final discussion of the results and interpretations.

\section{ACKNOWLEDGEMENTS}

This work is supported by the Russian Science Foundation (grant no. 19-77-10066). We acknowledge support for field logistics and lab analytics from the Russian Scientific Arctic Expedition on Spitsbergen Archipelago (RAE-S), Barentsburg. S.W. was supported by the Deutsche Forschungsgemeinschaft (grant no. WE4390/7-1).

\section{CONFLICT OF INTEREST}

The authors declare that they have no conflicts of interest.

\section{ORCID}

Vasiliy Demidov (D) https://orcid.org/0000-0002-6109-910X Sebastian Wetterich (D) https://orcid.org/0000-0001-9234-1192 Anton Terekchov (D) https://orcid.org/0000-0002-8300-6883

\section{REFERENCES}

1. Mackay JR. Pingos of the Tuktoyaktuk Peninsula Area, Northwest Territories. Geographie physique et Quaternaire, Les Presses de I'Universite de Montreal. Montreal. 1979;33(1):3-61.

2. Müller F. Observation on pingos. From Meddelelser om Grønland. Vol. 153 NO. 3: 127 pp., technical translation by D.A. Sinclair. Ottawa, Canada: National Research Council of Canada; 19591963.

3. Wetterich S, Schirrmeister L, Nazarova L, et al. Holocene thermokarst and pingo development in the Kolyma Lowland (NE Siberia). Permafr Periglac Process. 2018;29(3):182-198.

4. Liestøl O. Pingos, springs, and permafrost in Spitsbergen. Norsk Polarinstitutt Årbok. 1977;1975:7-29.

5. Liestøl O. Open-system pingos in Spitsbergen. Norsk Geografisk Tidsskrift. 1996;50(1):81-84.

6. Hjelle A. Geology of Svalbard, Polarhåndbok No. 7. Oslo, Norway: NorskPolarinstitutt; 1993.

7. Ross N, Harris C, Christiansen HH, Brabham PJ. Ground penetrating radar investigations of open system pingos, Adventdalen, Svalbard. Norsk Geografisk Tidsskrift. 2005;59(2):129-138.

8. Rossi G, Accaino F, Boaga J, Petronio L, Romeo R, Wheeler W. Seismic survey on an open pingo system in Adventdalen Valley, Spitsbergen, Svalbard. Near Surf Geophys. 2018;16(1):1-15.
9. Demidov N, Wetterich S, Verkulich S, et al. Geochemical signatures of pingo ice and its origin in Grondalen, West Spitsbergen. Cryosphere. 2019:13(11):3155-3169.

10. Yoshikawa K. Notes on open-system pingo ice, Adventdalen, Spitsbergen. Permafr Periglac Process. 1993;4(4):327-334.

11. Yoshikawa K, Harada K. Observations on nearshore pingo growth, Adventdalen, Spitsbergen. Permafr Periglac Process. 1995;6(4): 361-372.

12. Matsuoka N, Sawaguchi S, Yoshikawa K. Present-day periglacial environments in Central Spitsbergen, Svalbard. Geogr Rev Japan. 2004; 77(5):276-300.

13. Orvin AK. Litt om Kilder pa Svalbard. Norsk Geografisk Tidsskrift. 1944;X(1):16-38. (in Norwegian)

14. Hodson AJ, Nowak A, Redeker KR, Holmlund ES, Christiansen HH, Turchyn AV. Seasonal dynamics of methane and carbon dioxide evasion from an open system pingo: Lagoon pingo, Svalbard. Front Earth Sci. 2019;7(30):1-12.

15. Hodson A, Nowak A, Senger K, et al. Open system pingos as hotspots for sub-permafrost methane emission in Svalbard. Cryosphere. 2020; 14(11):3829-3842. https://doi.org/10.5194/tc-14-3829-2020

16. Humlum O, Instanes A, Sollid JL. Permafrost in Svalbard: a review of research history, climatic background and engineering challenges. Polar Res. 2003;22(2):191-215.

17. Christiansen HC. Ice wedges in Adventdalen. In: Sollid JL, Christiansen $\mathrm{HH}$, eds. Permafrost and periglacial features and glaciers in Svalbard. Excursion guide. VIII. International Conference on Permafrost. Dept. of Physical Geography, University of Oslo, Rapp. Ser. I Naturgeogr. Vol.14; Oslo: University of Oslo; 2003:112-116.

18. Kurkov AV, Neizvestnov YV. Groundwater aquifers of Spitsbergen archipelago. Engineering geology, Geomorphology of Spitsbergen Archipelago. Sevmorgeo. Leningrad. 1983;1983:41-53. (in Russian)

19. Demidov NE, Borisik AL, Verkulich SR, et al. Geocryological and hydrogeological conditions of western part of Nordenskiöld Land (Spitsbergen archipelago). Izv Atmos Ocean Phys. 2020;56: 1376-1400. https://doi.org/10.1134/S000143382011002X

20. Obidin NI. New data on groundwater and permafrost around Soviet mines on Spitsbergen by studies of 1952-1954. Works of NII of Arctic Geology of Ministry of Geology of USSR. Leningrad. 1958;85(9): 129-140. (in Russian)

21. Kasatkin AD, Misnik MY. Waterflow into coal mines of Barentsburg and Piramiden on Spitsbergen island. Hydrogeology. Engineering geology, geomorphology of Spitsbergen Archipelago. Sevmorgeo. Leningrad. 1983;54-66. (in Russian)

22. Gohman VV. Distribution and formation conditions of glacial icings of Spitsbergen. Mater Glaciol Res Moscow. 1987;68-75. (in Russian)

23. Demidov NE, Verkulich SR, Karaevska ES, Nikulina AL, Savatyugin LM. First results of permafrost observations at the monitoring site of the Russian Scientific Centre on Spitsbergen. Prob Arctic Antarct. 2016;4(110):67-79. (in Russian)

24. Christiansen $\mathrm{HH}$, Gilbert GL, Demidov N, et al. Permafrost thermal snapshot and active-layer thickness in Svalbard 2016-2017, In: SESS report 2018, The State of Environmental Science in Svalbard - an annual report, Eds.: Orr, E., Hansen, G., Lappalainen, H., Hübner, C., Lihavainen, H., SIOS, Longyearbyen, Svalbard, 2019; 26-47.

25. Geological Map Svalbard 1:100 000. Isfjorden (G100) - B9G. Norsk Polarinstitutt Temakart nr. 16, 1992

26. Verkulich S, Zazovskaya E, Pushina Z, et al. The postglacial environmental changes in vicinity of the Barentsburg settlement (West Spitsbergen), EGU General Assembly, Vienna, Austria, 8-13 April 2018, EGU 2018-7729, 2018.

27. Lavrentiev II. Structure and behavior of Nordenskiöld Land (Spitsbergen) glaciers by remote sensing. PhD thesis, Moscow, 2008: 17-19 (in Russian).

28. French H, Shur Y. The principles of cryostratigraphy. Earth Sci Rev. 2010;101(3-4):190-206. 
29. Dansgaard W. Stable isotopes in precipitation. Tellus. 1964;16(4): 436-468.

30. Shumsky PA. Fundamentals of structural ice-science. Moscow. 1955; 112-138. (in Russian)

31. Chizhova JN, Vasil'chuk YK. Use of stable water isotopes to identify stages of the pingo ice core formation. Ice Snow. 2018;58(4):507-524. (in Russian)

32. Mackay JR. Seasonal growth bands in pingo ice. Can J Earth Sci. 1990; 27(8):1115-1125.

33. Shokr M, Sinha N. Sea ice: physics and remote sensing. Chichester, UK: John Wiley and Sons; 2015.

34. Nazintsev UL, Panov VV. Phase composition and thermophysical properties of sea ice. St. Petersburg, Russia: Gidrometeoizdat; 200083 (in Russian).

35. Hornum MT, Hodson AJ, Jessen S, Bense V. Senger, Kim.: Numerical modelling of permafrost spring discharge and open-system pingo formation induced by basal permafrost aggradation. Cryosphere. 2020; 14(12):4627-4651. https://doi.org/10.5194/tc-14-4627-2020

36. Dallman WK (Ed). Geoscience Atlas of Svalbard. 2nded ed. Technical editor. Tromso, Norway: Norsk Polarintsitutt:71-85 2019: 71-85.

37. Postnov IS. Mineral waters of Spitsbergen. Engineering geology, Geomorphology of Spitsbergen Archipelago. Sevmorgeo. Leningrad. 1983;5-15. (in Russian)

38. Geological Map Svalbard 1:100 000. Adventdalen (G100) - C9G. Norsk Polarinstitutt Temakart nr. 31, 2001.

39. Sharin VV, Kokin OV, Gusev EA, Okunev AS, Arslanov HA Maksimov FE. New geochronological data on Quaternary deposits of north-western part of Nordenskiold Land (Spitsbergen Archipelago). Vol. 7. Saint Petersburg, Russia: Vestnik SPbGU; 2014:159-168 (in Russian).

40. Romanovskiy NN. Underground waters of the permafrost zone. Moscow, Russia: Moscow State University Press; 1983232 pp (in Russian).

41. Streletskaya ID. Patterns of spatial distributions of saline frozen sediments and cyopegs on Bovanenkovo gas field. PhD Thesis. Moscow, 1991 (in Russian).

42. Yoshikawa K, Lawson D, Sharkhuu N. Stable isotope composition of ice core in open- and closed-system pingos. In: Hinkel KM, ed. Salekhard, 25-29 June 2012. V. 1Permafrost, Tenth International Conference, Proceedings. Salekhard, Russia: The Northern Publisher; 2012:473-478.

43. Ekaykin AA, Lipenkov VY, Kozachek AV, Vladimirova DO. Stable water isotopic composition of the Antarctic subglacial Lake Vostok: implications for understanding the lake's hydrology. Isotopes Environ Health Stud. 2016;1-9.

44. Skakun AA, Chikhachev KB, Ekaykin AA, et al. Stable isotopic content of atmospheric precipitation and natural waters in the vicinity of Barentsburg (Svalbard) in 2016-2017. Ice Snow. 2020;60(3):379-394. (In Russian)

45. Vasil'chuk YK. Massive ground ice within Bovanenkovo gas field. Eng Geol. 2010;3:50-67. (In Russian)

46. Lipenkov VY, Ekaykin AA, Polyakova EV, Raynaud D. Characterization of subglacial Lake Vostok as seen from physical and isotope properties of accreted ice. Phil Trans R Soc. 2016;1-15.

47. Svendsen J. I and Mangerud, J.; Holocene glacial and climatic variations on Spitsbergen, Svalbard. Holocene. 1997;7(1):45-57.

48. Gilbert LG. Cryostratigraphy and sedimentology of high-Arctic fjord valleys. PhD Thesis. Norway: University of Bergen; 2018:1-28.

49. Birks $\mathrm{HH}$. Holocene vegetational history and climatic change in west Spitsbergen - Plant macrofossils from Skardjørna, an Arctic lake. Holocene. 1991;1(3):209-218.

50. Salvigsen O, Forman SL, Miller GH. Thermophilous molluscs on Svalbard during the Holocene and their paleoclimatic implications. Polar Res. 1992;11(1):1-10.

51. Svendsen J. I and Mangerud, J.: Paleoclimatic inferences from glacial fluctuations on Svalbard during the last 20000 years. Climate Dynam. 1992;6(3-4):213-220.

How to cite this article: Demidov V, Wetterich S, Demidov N, et al. Pingo drilling reveals sodium-chloride-dominated massive ice in Grøndalen, Spitsbergen. Permafrost and Periglac Process. 2021;1-15. https://doi.org/10.1002/ppp.2124 